\title{
Oil-Fueled Equipment Research: Program Plan
}

R. A. Hutchinson

September 1986

Prepared for the U.S. Department of Energy under Contract DE-AC06-76RLO 1830

Pacific Northwest Laboratory Operated for the U.S. Department of Energy by Battelle Memorial Institute 


\title{
DISCLAIMER
}

This report was prepared as an account of work sponsored by an agency of the United States Government. Neither the United States Government nor any agency thereof, nor any of their employees, makes any warranty, express or implied, or assumes any legal liability or responsibility for the accuracy, completeness, or usefulness of any information, apparatus, product, or process disclosed, or represents that its use would not infringe privately owned rights. Reference herein to any specific commercial product, process, or service by trade name, trademark, manufacturer, or otherwise, does not necessarily constitute or imply its endorsement, recommendation, or favoring by the United States Government or any agency thereof. The views and opinions of authors expressed herein do not necessarily state or reflect those of the United States Government or any agency thereof.

\author{
PACIFIC NORTHWEST LABORATORY \\ operated by \\ BATTELLE \\ for the \\ UNITED STATES DEPARTMENT OF ENERGY \\ under Contract DE-AC06-76RLO 1830
}

\begin{tabular}{|c|c|}
\hline \multicolumn{2}{|c|}{ Printed in the United States of America } \\
\hline \multicolumn{2}{|c|}{ Available from } \\
\hline \multirow{4}{*}{\multicolumn{2}{|c|}{$\begin{array}{c}\text { National Technical Information Service } \\
\text { United States Department of Commerce } \\
5285 \text { Port Royal Road } \\
\text { Springfield, Virginia } 22161\end{array}$}} \\
\hline & \\
\hline & \\
\hline & \\
\hline \multirow{2}{*}{\multicolumn{2}{|c|}{$\begin{array}{l}\text { NTIS Price Codes } \\
\text { Microfiche A01 }\end{array}$}} \\
\hline & \\
\hline \multicolumn{2}{|c|}{ Printed Copy } \\
\hline & Price \\
\hline Pages & Codes \\
\hline $001-025$ & $\mathrm{~A} 02$ \\
\hline $026-050$ & $\mathrm{AO3}$ \\
\hline $051-075$ & A04 \\
\hline $076-100$ & A05 \\
\hline $101-125$ & A06 \\
\hline $126-150$ & A07 \\
\hline $151-175$ & $A 08$ \\
\hline $176-200$ & $A 09$ \\
\hline $201-225$ & A010 \\
\hline $226-250$ & A011 \\
\hline $251-275$ & $\mathrm{~A} 012$ \\
\hline $276-300$ & $\mathrm{~A} 013$ \\
\hline
\end{tabular}


OIL-FUELED EQUIPMENT RESEARCH:

PROGRAM PLAN

R. A. Hutchinson

September 1986

Prepared for

the U.S. Department of Energy

under Contract DE-AC06-76RLO 1830

Pacific Northwest Laboratory

Richland, Washington 99352 
The purpose of this document is to define the basis for a U.S. Department of Energy (DOE) program for oil-fueled equipment research. The needs for and benefits of the technical research are explained, and a research plan is presented. This program was developed by Pacific Northwest Laboratory (PNL) with assistance from Steven Winters Associates and input from Brookhaven National Laboratory, Oak Ridge National Laboratory, and many representatives of the heating-oil and oil-fueled equipment industries. The private sector input was extensive, obtained through a series of workshops and formal and informal surveys. The planning effort was directed by the Building Equipment Division of the DOE Office of Buildings and Community Systems.

$0 i 1$ heating of residences and commercial buildings is certain to remain an important part of the energy sector well into the future, yet technological development in this area has been slow. This is largely because the mature market sector gives little incentive for equipment manufacturers to invest in $R \& D$, and because the independently operated oil distribution companies, unlike the more regulated gas and electric utilities, cannot fund major R\&D work and still remain competitive. The benefits from improved oil heating technology, however--improved equipment efficiency, ability to maintain diverse usable energy resources, increased safety, decreased pollution, and resistance to foreign competition--have obvious attraction to oil consumers as well as the oil heating industry.

The objective of the oil-fueled equipment research program is to develop the technological basis for new equipment and operating strategies based on improved understanding of oil-burning fundamentals. The program will provide the oil-fueled equipment industry with the basis for developing a new, hightech generation of equipment, and the oil distributors and equipment installers and consumers with improved knowledge of how best to install and operate such equipment.

The planned research will focus on the long-term need for improved seasonal as well as steady-state equipment performance. This is because in actual operation, some of the inefficiency of even the best oil-fueled equipment is 
the result of the equipment's inability to be modulated. In addition, the performance of all systems degrades over time. Though this degradation varies with each installation and each heating season, a top-of-the-line oil furnace ( $85 \%$ steady-state efficient) yields seasonal performance of perhaps $50 \%-60 \%$ efficiency several years later. Many facets of this complex problem will be addressed in this program plan.

Most of the proposed work is generic, highly technical research, but educational and technology transfer elements play a key role in the success of the program. The technical research covers all aspects of producing new, seasonally efficient oil-fueled equipment concepts, and the research areas complement each other in producing both short-and long-term benefits. The cornerstone of the program is research in oil combustion, but other areas are also vital to the technology of oil-fueled conversion systems. Diagnostics must be developed to monitor the process of oil combustion, particularly soot production. The role of fuel quality in combustion must be identified. Heat transfer surface analysis and design are needed to discover how to transfer highly variable amounts of heat using a single device. New methods of venting exhaust gases not dependent on chimneys must be developed. Controls that can handle the variable firing and improved cycling strategy approaches must be designed. Finally, the results of all these activities must be synthesized into innovative equipment concepts.

Though fundamental research is required, many elements of the work will also address immediate problems, providing improved technology that can be used in designing improved versions of conventional equipment. This benefit of the work is an important reason for the industry support enjoyed by this program, in addition to the long-term benefits from new generations of equipment. 


\section{CONTENTS}

SUMMARY $i j i$

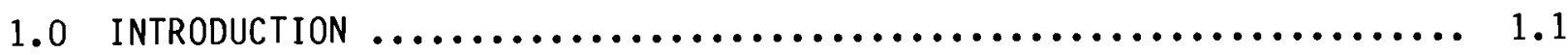

1.1 PROGRAM OBJECTIVE AND SCOPE $\ldots \ldots \ldots \ldots \ldots \ldots \ldots \ldots \ldots \ldots \ldots \ldots \ldots$

1.2 DOCUMENT ORGANIZATION $\ldots \ldots \ldots \ldots \ldots \ldots \ldots \ldots \ldots \ldots \ldots \ldots \ldots \ldots \ldots \ldots$

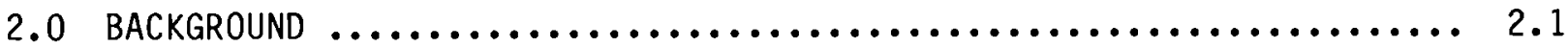

2.1 OIL USE STATISTICS $\ldots \ldots \ldots \ldots \ldots \ldots \ldots \ldots \ldots \ldots \ldots \ldots \ldots \ldots \ldots \ldots \ldots \ldots \ldots \ldots \ldots$

2.2 FUEL USER CHARACTERISTICS $\ldots \ldots \ldots \ldots \ldots \ldots \ldots \ldots \ldots \ldots \ldots \ldots \ldots \ldots \ldots \ldots \ldots \ldots \ldots$

2.3 WHY OIL USE WILL CONTINUE $\ldots \ldots \ldots \ldots \ldots \ldots \ldots \ldots \ldots \ldots \ldots \ldots \ldots \ldots$

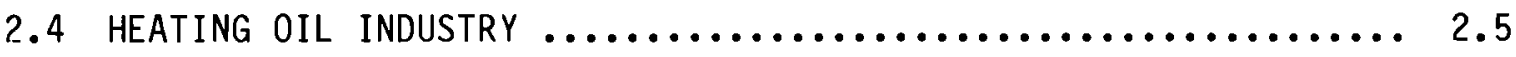

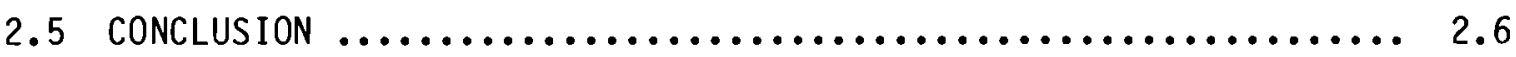

3.0 BENEF ITS FROM IMPROVED TECHNOLOGY $\ldots \ldots \ldots \ldots \ldots \ldots \ldots \ldots \ldots \ldots \ldots \ldots \ldots$

3.1 EfF IC IENCY IMPROVEMENTS $\ldots \ldots \ldots \ldots \ldots \ldots \ldots \ldots \ldots \ldots \ldots \ldots \ldots \ldots \ldots \ldots \ldots$

3.2 CONTINUED ABILITY TO USE DIVERSE FUELS $\ldots \ldots \ldots \ldots \ldots \ldots \ldots \ldots \ldots$

3.3 SAFETY AND EMISSIONS CONSIDERATIONS $\ldots \ldots \ldots \ldots \ldots \ldots \ldots \ldots \ldots \ldots . . \ldots$

3.4 FOREIGN COMPETITION $\ldots \ldots \ldots \ldots \ldots \ldots \ldots \ldots \ldots \ldots \ldots \ldots \ldots \ldots \ldots \ldots \ldots \ldots \ldots \ldots \ldots \ldots \ldots$

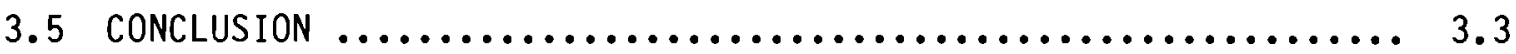

4.0 PAST RESEARCH EFFORTS $\ldots \ldots \ldots \ldots \ldots \ldots \ldots \ldots \ldots \ldots \ldots \ldots \ldots \ldots \ldots \ldots \ldots \ldots$

4.1 INDUSTRY-SPONSORED RESEARCH PROGRAMS FOR ADVANCED OIL HEATING

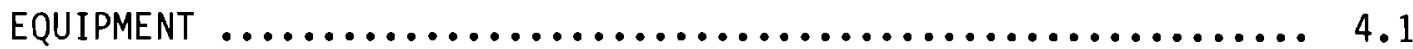

4.2 GOVERNMENT-SPONSORED RESEARCH PROGRAMS FOR ADVANCED OIL
HEATING EQUIPMENT $\ldots \ldots \ldots \ldots \ldots \ldots \ldots \ldots \ldots \ldots \ldots \ldots \ldots \ldots \ldots \ldots \ldots \ldots \ldots . .2$

4.3 CONFERENCES TO IDENTIFY OIL HEAT RESEARCH NEEDS $\ldots \ldots \ldots \ldots \ldots \ldots 4.4$

5.0 TECHNICAL BACKGROUND $\ldots \ldots \ldots \ldots \ldots \ldots \ldots \ldots \ldots \ldots \ldots \ldots \ldots \ldots \ldots \ldots \ldots \ldots$

5.1 CURRENT STATUS AND PROGRAM THRUST $\ldots \ldots \ldots \ldots \ldots \ldots \ldots \ldots \ldots \ldots \ldots . \ldots \ldots$

5.2 TECHNICAL PROBLEM AREAS $\ldots \ldots \ldots \ldots \ldots \ldots \ldots \ldots \ldots \ldots \ldots \ldots \ldots \ldots \ldots$ 


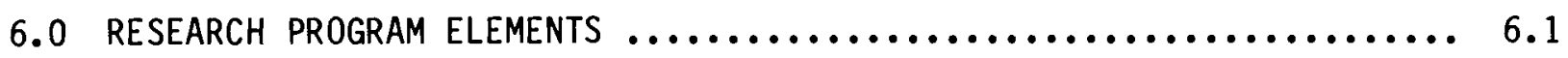

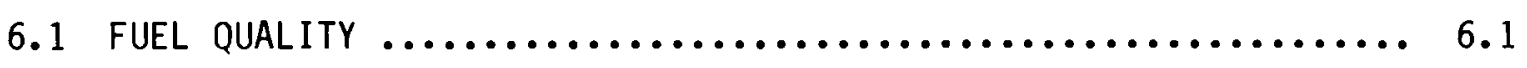

6.2 FUEL OIL COMBUStiON $\ldots \ldots \ldots \ldots \ldots \ldots \ldots \ldots \ldots \ldots \ldots \ldots \ldots \ldots, 6.3$

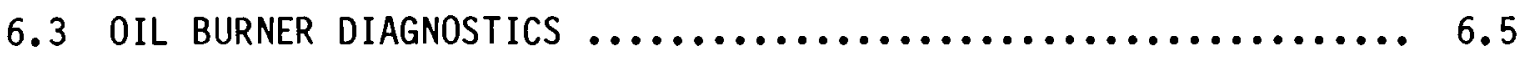

6.4 ADVANCED HEAT EXCHANGERS $\ldots \ldots \ldots \ldots \ldots \ldots \ldots \ldots \ldots \ldots \ldots \ldots, 6.7$

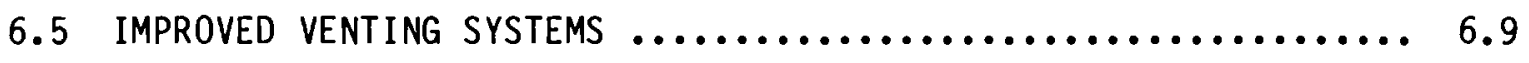

6.6 ADVANCED COMBUStion SYSTEMS $\ldots \ldots \ldots \ldots \ldots \ldots \ldots \ldots \ldots \ldots \ldots, 6.10$

6.7 ADVANCED EquipMENT CONTROL STRATEgIES $\ldots \ldots \ldots \ldots \ldots \ldots \ldots \ldots . \ldots .11$

6.8 EDUCATIONAL AND TECHNOLOGY TRANSFER ACTIVITIES $\ldots \ldots \ldots \ldots \ldots, 6.12$

7.0 PROGRAM RESOURCES AND MANAGEMENT $\ldots \ldots \ldots \ldots \ldots \ldots \ldots \ldots \ldots \ldots \ldots . \ldots \ldots . . \ldots \ldots$

7.1 MANAGEMENT StRUCTURE $\ldots \ldots \ldots \ldots \ldots \ldots \ldots \ldots \ldots \ldots \ldots \ldots \ldots \ldots \ldots . . \ldots \ldots \ldots$

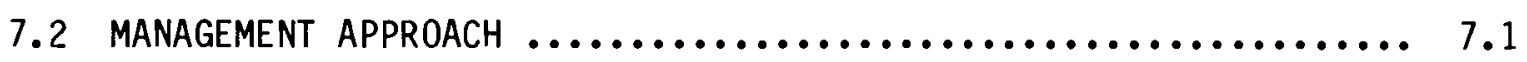

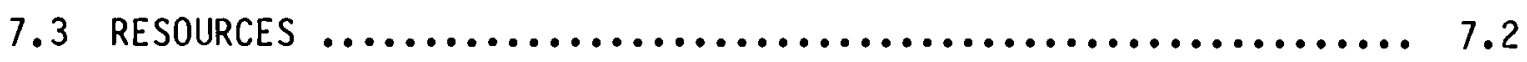

8.0 RefEREnCES $\ldots \ldots \ldots \ldots \ldots \ldots \ldots \ldots \ldots \ldots \ldots \ldots \ldots \ldots \ldots \ldots \ldots \ldots \ldots \ldots, 8.1$

APPENDIX A - PROGRAM ENERGY SAVINGS $\ldots \ldots \ldots \ldots \ldots \ldots \ldots \ldots \ldots \ldots \ldots \ldots \ldots . \ldots \ldots . \ldots \ldots$ 
FIGURES

1 Regional Distribution of Residential $0 i 1$ Use $\ldots \ldots \ldots \ldots \ldots \ldots \ldots \ldots . . . . .2$

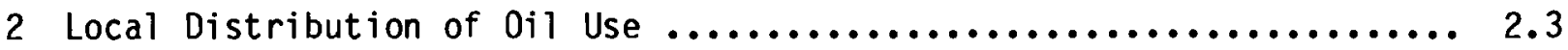

3 Fuel $0 i 1$ Consumption and Annual Heating Degree-Days per Fuel $0 i 1$ Heated Home--1978 to 1982 .................................... 2.4

4 Qualitative Performance Improvements $\ldots \ldots \ldots \ldots \ldots \ldots \ldots \ldots \ldots \ldots \ldots \ldots . \ldots . \ldots$

5 Program Research Elements $\ldots \ldots \ldots \ldots \ldots \ldots \ldots \ldots \ldots \ldots \ldots \ldots \ldots \ldots \ldots \ldots . \ldots . \ldots . \ldots$

6 Possible Research Element Phasing $\ldots \ldots \ldots \ldots \ldots \ldots \ldots \ldots \ldots \ldots \ldots \ldots \ldots . \ldots . \ldots . \ldots$

$\underline{T A B L E}$

A. 1 Annual Energy Savings After Program Completion--Residential

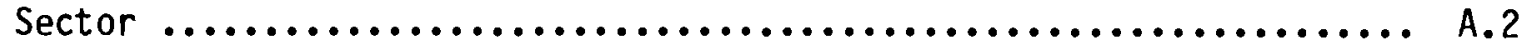




\subsection{INTRODUCTION}

This multi-year program plan for oil-fueled equipment research was developed by Pacific Northwest Laboratory $(P N L)(a)$ with assistance from Steven Winters Associates and input from Brookhaven National Laboratory, Oak Ridge National Laboratory, and many representatives of the heating $0 i 1$ and oil-fired equipment industries. The planning effort was directed by the Building Equipment Division of the U.S. Department of Energy (DOE) Office of Buildings and Community Systems.

\subsection{PROGRAM OBJECTIVE AND SCOPE}

The objective of the oil-fueled equipment program is to develop new equipment concepts and operating strategies based on improved understanding of oilburning fundamentals. A successful program will provide industry with the technological basis for a new, highly efficient generation of equipment, and oil distributors and equipment buyers with improved knowledge of how best to install and operate such equipment.

The research carried out by this program is of a long-term nature, with high technical and financial risks. It could not and will not be carried out by current oil-fueled equipment manufacturers, nor by a collaboration of oil refiners or distributors. The program will take several years to complete, and provide a variety of intermediate results. These include fundamental data directly from experiments, new component design approaches, computer analyses and design tools, and diagnostic and testing methods. The final result will be experimental versions of completely new types of equipment.

\subsection{DOCUMENT ORGANIZATION}

This document's primary function is to present the structure and rationale of the oil-fueled equipment research program. Chapter 2 contains background material on the nature of the oil heating industry and its consumers. Chapter 3 outlines the expected benefits arising from research results, both in

(a) Operated for the U.S. Department of Energy by Battelle Memorial Institute. 
terms of energy savings and in terms of maintenance of technological

strength. Chapter 4 provides an overview of previous research in this field, including past DOE work. Chapter 5 outlines the primary technical needs to be addressed by the oil-fueled equipment program. Chapters 6 and 7 discuss the technical research approach, the research elements, program management, resources, and schedule. 


\subsection{BACKGROUND}

This chapter outlines basic characteristics of U.S. heating oil markets. It then discusses the infrastructure for heating oil, which is very different from the geographic monopoly held by suppliers of the other primary home energy sources, electricity and gas. Finally, it emphasizes important technological and energy conservation issues arising from the current situation.

\subsection{OIL USE STATISTICS}

Fuel oil is a major source of home and commercial heat in the United States today. In residences it is used for either space (85\%) or water (15\%) heating. The Department of Energy's Residential Energy Consumption Survey (EIA 1984) indicates that in the 1982 heating year about 18\% (over 15 million) of all households were in part heated with oil or kerosene (the survey data consider oil together with kerosene) and, of those, $12 \mathrm{million}$ households were heated primarily with oil or kerosene. This use was concentrated in certain regions in the eastern half of the country.

Commercial users are similarly distributed, and burn virtually the same total amount of $0 i 1$ as residential users: about 1 quad per year, in recent years. In 1983, 1.08 quads of oil were used for residential heating, and 0.89 quads for commercial heating (BCS 1983).

The residential energy consumption in these regions can be specifically examined using the survey data. In the 1982 heating year, New England consumed $21 \%$, the Mid-Atlantic states $48 \%$, the South Atlantic states $14 \%$, and the East North Central states $11 \%$ (for a total of 94\%) of the 1.14 quads (9.6 billion dollars worth) of $0 i 1$ burned for home heating as shown in Figure 1. With the exception of the South Atlantic states, these regions have long, cold winters. The data show that $85 \%$ of the oil users live in regions with an average of more than 4000 heating degree-days per year compared with $60 \%$ for those using gas and 55\% for those using electricity as the main heating source. In addition, these regions of the country are more densely populated than the 


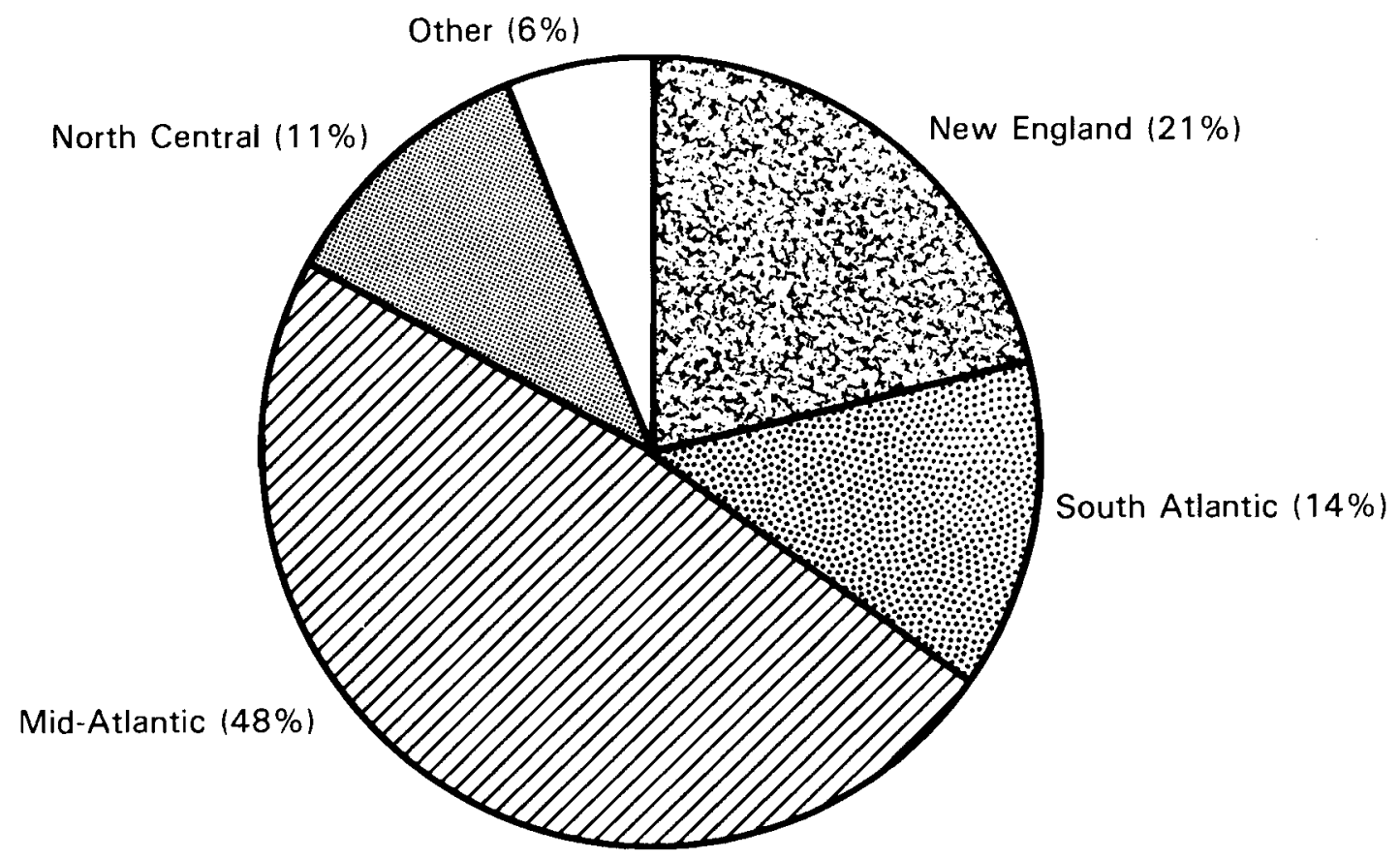

FIGURE 1. Regional Distribution of Residential 0il Use (EIA 1984)

remainder. Nonetheless, compared to the average, fewer of the oil users live in central cities ( $30 \%$ versus $35 \%$ ), and more live in suburbs ( $45 \%$ versus $40 \%$ ), as shown in Figure 2 .

\subsection{FUEL USER CHARACTERISTICS}

There are special aspects of the profile of home oil users as found in the Residential Energy Consumption Survey (EIA 1985), in addition to their regional concentration, their high correlation with cold weather, and their tendency to be dispersed away from city centers. First, oil users are much older than the average householder in this country. They are also far more likely than average to live in a very old home: almost half of all 0il-or kerosene-heated homes were built before 1939, whereas very few electric- or gas-heated ones were. These homes are often poorly insulated, large, and drafty, requiring a considerable investment to bring them up to modern insulation standards. Improved oil-fueled equipment is therefore especially important, as it may be far more cost effective than building modifications. 


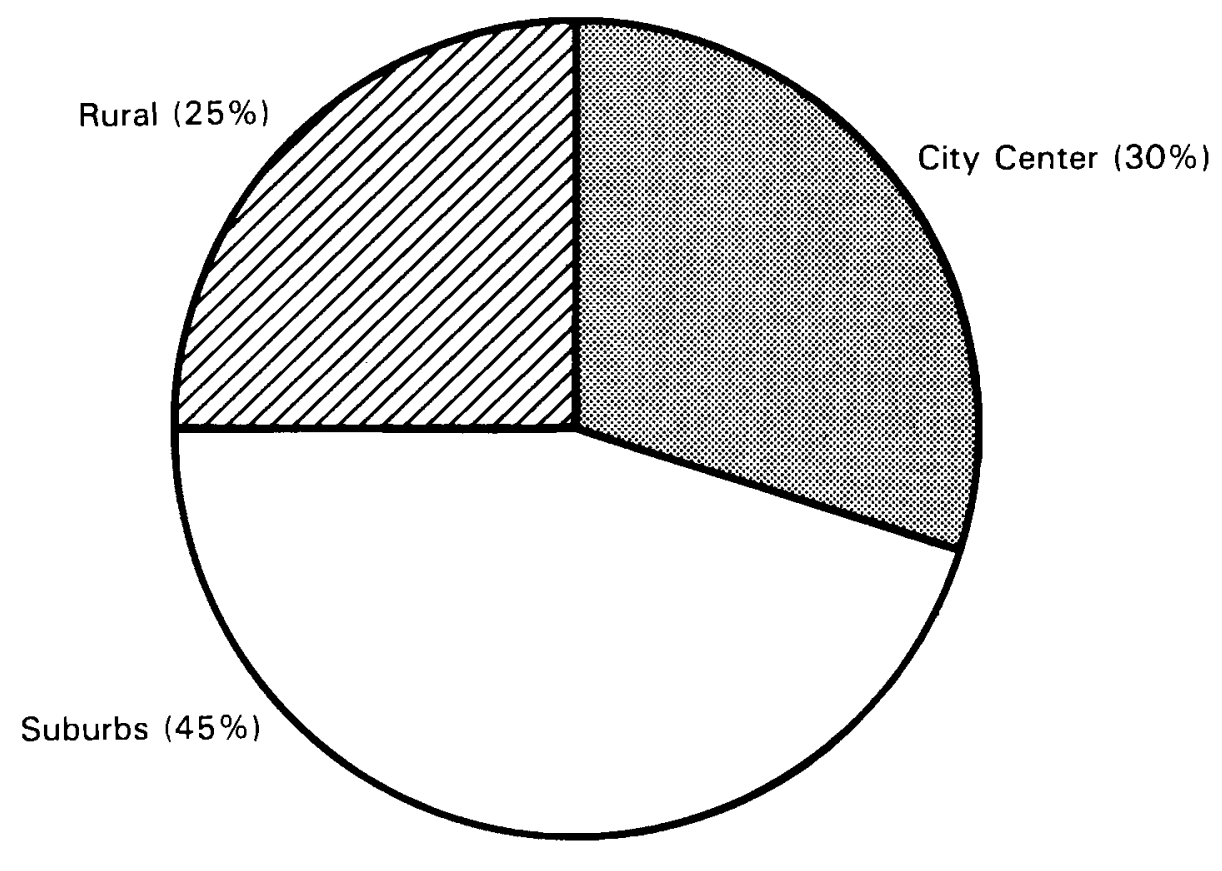

FIGURE 2. Local Distribution of $0 i 1$ Use (EIA 1984)

Second, oil users spend a greater portion of their income on heating energy than the national average. Because the oil users are gathered in the Northeast, where the climate is cold and the homes are older, the four regions in which oil use is most common are those in which individuals spend the greatest percentage of their money on housing energy. The poor are especially hard hit, paying about $30 \%$ of their income on energy bills in New England and the Mid-Atlantic states, $24 \%$ in the South Atlantic, and $22 \%$ in the East North Central States. Since more than half of the nation's poor live in these regions--about 6.7 million of the nation's 12.1 million people below the poverty line in 1982--inefficiencies in oil heating equipment, and the resultant unnecessarily high fuel bills, cause particular problems.

\subsection{WHY OIL USE WILL CONTINUE}

$0 i 1$ 's percentage of the U.S. residential and commercial energy markets has been declining for the last 25 years (see Figure 3), a trend begun even before the oil price shocks of 1973 and 1979 (Schipper and Ketoff 1985; BCS 1985). This is largely because few new houses specify oil heat, and many homeowners 


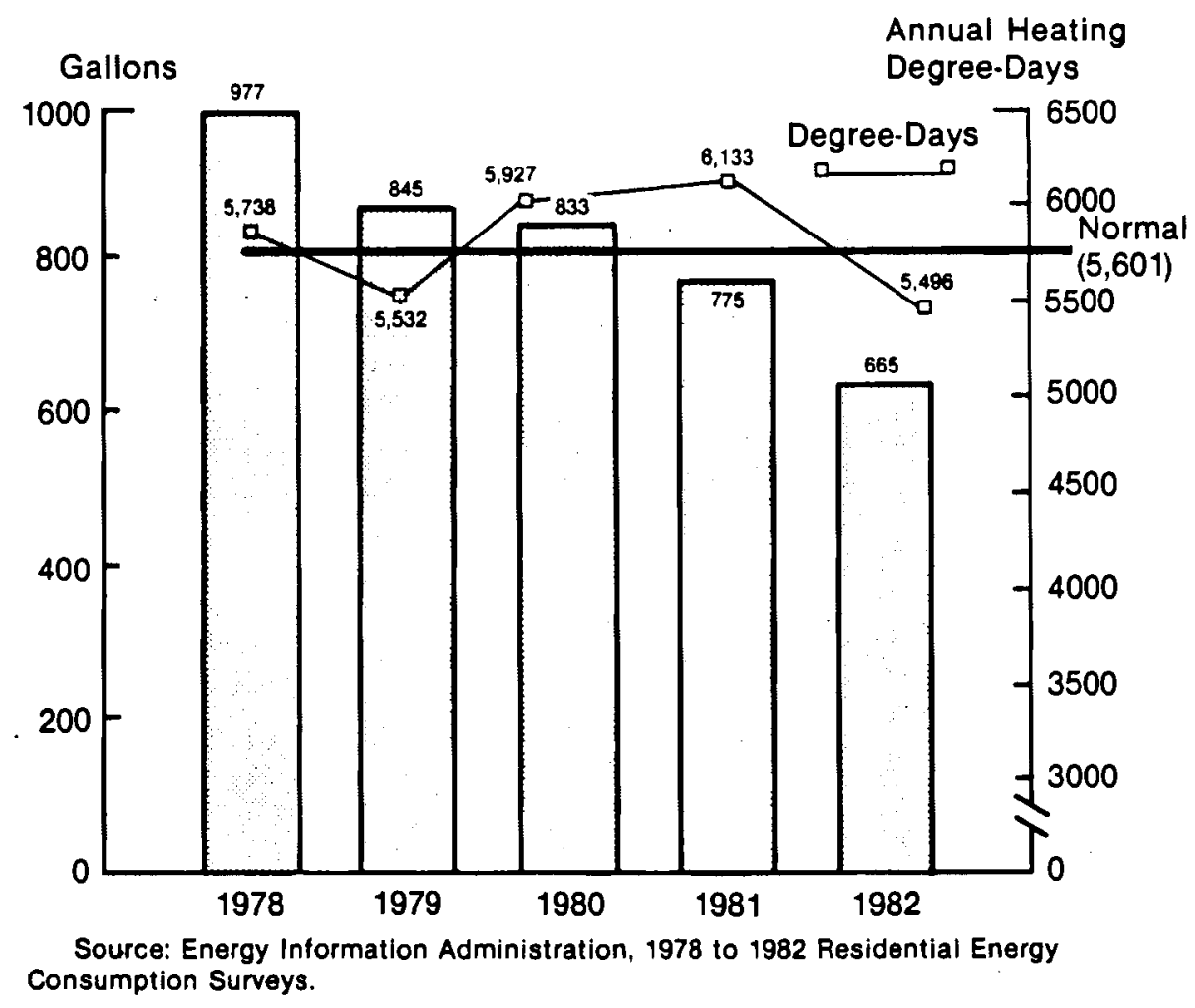

RECS: Consumption and Expenditures, Aprll 1982 Through March 1983: National Data Energy Information Administration

FIGURE 3. Fuel $0 i 1$ Consumption and Annual Heating Degree-Days per Fuel 0il Heated Home--1978 to 1982

are fuel switching. The amount of oil used per house has also declined since the price shocks, particularly since 1979. Reasons for the overall decline can be categorized as permanent fuel switching (to gas or electricity, particularly in older, larger homes or establishments that cost much more than average to heat), reversible fuel substitution (to wood, electric resistance heat or kerosene), behavioral changes (lowering thermostats), and conservation efforts (improvements such as insulation and weatherstripping or heating equipment replacement providing improved conversion of fuel to useful heat). Given the perturbations in international oil prices, fuel use may increase drastically with lower fuel cost because reversible savings are a major portion of the decline at present (Schipper and Ketoff 1985). 
Even without economic perturbations, experts on the subject believe that oil heating will remain steady in the foreseeable future. There are no direct and reasonable permanent substitutes for many of the 15 million current residential users, particularly for households with central heating. Most of the easy conversions have been made already. For these remaining users, gas is often unavailable, particularly since most users of oil heat are in the suburbs or in the country. Electricity can be prohibitively expensive, due to high electricity rates in regions where oil is prevalent, even when a heat pump is used. Heat pumps are less efficient in cold climates. Sometimes wood is substituted, but it is not always available or convenient, particularly for the elderly. Kerosene or electric radiant heaters are temporary substitutes at best and, like wood, may be questionable from the standpoint of health and safety.

\subsection{HEATING OIL INDUSTRY}

The heating oil industry is different from the other major sources of home heating energy, the electric and gas utilities. It does not have exclusive market territories, or any means to apply R\&D costs equitably to all customers. The manufacturers of oil products--the refiners--no longer support any R\&D activities on behalf of end users or heating equipment manufacturers. (Details of their past involvement are given in Chapter 4.) Such activity has disappeared largely because heating oil (\#2 fuel oil) now comprises only $11 \%$ of the distillate petroleum products market (EIA 1985). In addition, research to improve efficiency could initially cut the use of heating oil, and thus is not high on the oil suppliers' research agenda. Effective research as proposed here can be expected to eventually halt the slow erosion of heating oil markets, but technical and financial risks are great.

Heating oil, produced by the refinery, proceeds to a distributor. These individual heating oil marketers, unlike utilities, compete among themselves and cannot set a higher price to the consumer in order to finance R\&D. The regulated electricity and gas utilities do this, through the Electric Power Research Institute (EPRI) and the Gas Research Institute (GRI), with approval of the Federal Energy Regulatory Commission (FERC) and state public service 
commissions. However, even the planning of activities in this area is difficult, as there are no established groups or forums with which to work. Specific needs are not defined or prioritized by industry, as concerns of relevant industry groups tend to be those of short-term survival more than of long-term improvements.

0il-heating equipment manufacturers are in a similar situation. Few have spare research dollars available, and there are multiple short-term concerns to absorb any spare cash. Major improvements are likely to require investments and expertise beyond the abilities of the manufacturers in any case. Secondly, many companies diversified into manufacture of gas or electric heating devices many years ago and, barring major changes in relative energy prices, have $1 \mathrm{im-}$ ited incentive for doing research that may shift market share from one part of their operations to another. On the other hand, were some of these firms to make revolutionary advances in oil heating equipment, based on generic, well publicized government research, activity would accelerate rapidly. Domestic manufacturers are aware that overseas corporations are positioning themselves in heating, ventilation, and air conditioning (HVAC) equipment markets and have already demonstrated improvements to U.S. technology. The industry appears to be receptive to a technological push.

\subsection{CONCLUSION}

The discussion in the preceding sections brings out several primary points. First, oil heating of residences and commercial buildings is and will remain an important energy sector. The easy shifts away from oil have been completed, leaving a strong need for improved equipment for those who cannot change fuels. Industry will not undertake the needed R\&D; indeed, technology development in this sector has been stagnant for many years because of structural problems. 0il users, of whom a disproportionate number are below the poverty line, need low-cost, high-efficiency equipment that will reduce their (and the government's) energy bill. Equipment inefficiencies have also resulted in significant costs to oil producers, marketers, and in some cases equipment manufacturers because of the decline in oil use. 


\subsection{BENEF ITS FROM IMPROVED TECHNOLOGY}

There are four general categories of benefits from improved oil heating technology, which will be discussed here in approximate order of importance. These categories are efficiency improvements, maintenance of diversity of usable energy resources, increased safety and decreased pollution, and improved resistance to foreign competition.

\subsection{EFFICIENCY IMPROVEMENTS}

Efficiency improvements are the primary benefit from oil heating research, as well as the primary target of the research. These improvements mean lower fuel use in each energy conversion device. They also mean improved economics to consumers of oil, which can be expected to relieve pressure on customers currently using oil. Improved efficiency should also help some oil customers improve their standards of comfort in the home and reduce reliance on small electric, kerosene, and gas heaters and on wood burning.

Although the research program presented here consists of generic, fundamental research, rough estimates can be made for energy savings eventually resulting from the work. The procedure and worksheet for the estimates are in Appendix A. Savings reach a level of 0.27 quads per year ( 1.9 billion gallons of $0 i 1$; 45 million barrels) by the year 2010 (at which point the research program will have long been completed).

\subsection{CONTINUED AB ILITY TO USE DIVERSE FUELS}

The established national energy policy is to maintain or improve the ability to use a variety of fuels. This has typically focused on reducing oil use, for in the context of national energy policy it is the one fuel that has achieved strategic value. In the case of residential and commercial heating it is the ability to efficiently use oil that needs improvement. Our lagging oilburning technology will be even more important in the future, as current subtle trends lowering heating oil quality continue and better technology becomes necessary in order to effectively use the fuel. Ability to optimally utilize 
this type of fuel is also important from a national security viewpoint, for defense as well as long-term energy reasons.

\subsection{SAFETY AND EMISSIONS CONSIDERATIONS}

$0 i 1$ is virtually unique in being portable, storable, and safe to handle, yet having high energy content and being relatively clean to burn. Improved oil heating technology should decrease wood burning as well as localized electric resistance and kerosene heating. Current wood-burning practices cause significant pollution and safety hazards. Although research to improve this situation is proceeding, people who are shifting to wood burning from oil for economic reasons are less likely to use the latest technology or the best safety practices. Better economics for $0 i 1$ will improve this situation.

Localized electric resistance and kerosene heating are potentially more hazardous than the oil heat for which they are currently substituting, and kerosene may have emissions problems as well if the equipment is improperly operated.

Finally, the emissions of oil burning itself are relevant here. Although a properly maintained and operated oil burner nears $100 \%$ combustion efficiency and thus has very clean combustion, in operation this level can degrade considerably. Better combustion diagnostics and controls can minimize the production of many of the primary pollutants (e.g., carbon monoxide and unburned hydrocarbons), as well as keep the equipment's overall performance as efficient as possible. Combustion control, efficiency, and pollution control go hand-in-hand in this case.

\subsection{FOREIGN COMPETITION}

Although methods of residential heating vary because of culture and infrastructure as well as because of climate, Europe and Japan are significantly ahead of the United States in kerosene, propane, and oil heating technology. Indeed, large numbers of the kerosene heaters used to substitute for oil are made in Japan, where kerosene is a primary and traditional heat source. Europeans, particularly the Danes, the Germans, and the Swedes, have long had home heating markets far more dependent on oil than that of the United States. Far 
more new homes incorporate oil heat, and European manufacturers have continued to develop improved technologies while the U.S. industry has been stagnant. Imports have been limited because of sizing, codes and other complications, but this cannot be expected to remain the case forever. With fundamentally improved U.S. technology such imports could be reduced, and exports could even be expected. Indeed, technical cooperation should be possible; in previous decades Europeans came to the United States to learn the latest in oil heating, and for the present we must learn from them.

\subsection{CONCLUSION}

There are significant benefits to be gained from development of more efficient oil heating technologies. These benefits would accrue to almost all the groups involved--consumers through lower costs and decreased hardship for the poor and elderly, oil refiners and marketers through slower decreases or perhaps slight increases in market share, and the nation through lower overall energy use, decreased pollution, fewer safety hazards, and a more stable and secure industry. 


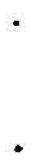




\subsection{PAST RESEARCH EFFORTS}

In order to put the proposed research plan into perspective, it is helpful to briefly summarize work that has been done in previous years. Past research activities related to oil heating equipment have centered on two major programs. The first is the industry-wide oil burner research program funded by the major oil companies through the American Petroleum Institute (API) from 1960 through 1967 and continued through 1974 by the National 0il Fuel Institute (NOFI). The second group of major research activities in recent years has been supported by the DOE through programs at Brookhaven National Laboratory and other research organizations. $0 i 1$ heat conferences have been held to present the current status of oil heating technology and to identify future research and development needs. These efforts are discussed in more detail in the following sections.

\subsection{INDUSTRY-SPONSORED RESEARCH PROGRAMS FOR ADVANCED OIL HEATING EQUIPMENT}

From 1960 through 1967, the major oil companies funded a significant research program to advance oil heat equipment technology. Individual oil companies supported this program by contributions to the API, and by R\&D efforts conducted within research departments operated by the oil companies. The overall goal of this program was to develop efficient, low-cost equipment with improved reliability to compete with natural gas-powered heating systems.

The API research program began with a needs survey (Locklin 1960) which was the basis for recommending research activities in several categories:

- combustion fundamentals and burner concepts, including atomization, vaporization, ignition, fuel/air mixing, combustion process and smoke formation, surface combustion, and experimental techniques

- equipment development, including burners, heat exchangers, and water heaters

- residential equipment applications, including fuel storage and exhaust gas venting 
- industry codes and standards

- new applications for fuel oil.

The API research program did not implement all of these recommendations; rather it focused on equipment development and made advances in the burner area of the program. It ended in 1966 when responsibility for oil heat research was transferred to NOFI, representing marketers and heating equipment manufacturers. Major oil companies continued to support oil heating equipment research and development through the commercialization of advanced equipment concepts.

Some important technical advances were produced by the API and NOF I research programs, notably the flame retention burner concept. Later work at Brookhaven demonstrated the improved efficiency of $f l$ ame retention burners, which helped to accelerate market acceptance of this efficient design.

The R\&D projects ended in 1974, when major oil company support was withdrawn, and NOFI merged with the National 0il Jobbers Council (NOJC). Now called the Petroleum Marketers Association of America (PMA), this organization does not have the funding support required for an R\&D program to develop improved oil heat equipment. The major oil companies have not sponsored research to develop advanced oil heating equipment since the API and NOFI programs ended.

A major nongovernment research organization, Battel le Columbus Laboratories $(B C L)$, has been directly involved with oil heat research programs for many years. $B C L$ recommended the industry-wide oil burner research program as part of the API research begun in 1960. BCL also has had government contracts in this area, as discussed below.

\subsection{GOVERNMENT-SPONSORED RESEARCH PROGRAMS FOR ADVANCED OIL HEATING EQUIPMENT}

The DOE has funded research activities to study oil heating systems and to develop advanced oil-burning equipment designs. The DOE programs focused primarily on efficiency-improving technological advances.

From 1976, Brookhaven National Laboratory has taken a leading role in the DOE's residential oil heat conservation programs. The Brookhaven activities 
included development of an efficiency test laboratory for oil-fired systems to identify energy-saving equipment designs and to evaluate the technical merit of production and prototype heating equipment. The Brookhaven work expanded to include subcontracted efforts by private organizations (Thermacore 1982; Mariano 1982), universities (Schladitz 1982), and individuals to develop advanced heating equipment and diagnostic methods for improving oil heat technology. The laboratory tests were used to characterize the performance of existing and new heating systems at full-and part-load so that the annual fuel use could be determined. Many retrofit options such as vent dampers, flue heat reclaimers, boiler water temperature controls, and new burner designs featuring reduced or variable firing rates were tested and analyzed (Woodworth and Dennehy 1961).

BCL completed a survey of oil heat technology for Brookhaven (Locklin and Hazard 1980), and also has an ongoing research program directed by Brookhaven on condensing heat exchangers (Ball et al. 1982; Razgaitas et al. 1984) to identify acceptable construction materials for high-efficiency boilers and furnaces. This program included a symposium on condensing heat exchangers ( $\mathrm{BCL}$ $1982)$.

One Canadian government agency, the Canadian Combustion Research Laboratory (CCRL), operated by the Canadian Department of Energy, Mines and Resources, has been particularly active, conducting research programs for oil heating systems for the past 14 years. This work has emphasized practical research projects designed to supply consumers and service technicians with useful guidelines for improving the efficiency of oil heating equipment, and has included evaluation of burner furnaces, new heating systems, smoke production levels, pollutant emissions, fuel properties, alternative fuels, and heating equipment modifications. Recent studies have focused on venting system improvements.

Important advances also are being made by governmental and private efforts in several European countries, including France, Sweden, and Germany. However, the results of such work are not, at present, readily accessible to the research effort in this country. 


\subsection{CONFERENCES TO IDENTIFY OIL HEAT RESEARCH NEEDS}

Conferences and meetings have been conducted in recent years to determine the present state of $0 i 1$ heat technology, and to identify existing research and development needs for improved equipment efficiency. These meetings included a Reston, Virginia, workshop on research needs for space conditioning (Andrews 1982), the Airlie House Building Energy Equipment Workshop held in December 1983, and the 0il Heat Technology Conference and Workshop held in September 1985 at Brookhaven National Laboratory. These conferences were organized by DOE, PMA, American Society of Heating, Refrigeration, and Air Conditioning Engineers (ASHRAE), NANB, American Institute of Architecture (AIA), and other concerned organizations, and attended primarily by those in the oil-fuel industry and related fields. They were oriented both toward discussion of immediate, practical problems and broad, sweeping, long-term technological issues. Several key areas received emphasis in most or all of these conferences, an indication that these areas are of chief concern to those in oil heat research and industry:

- fuel quality degradation

- low-firing-rate and modulating oil burners

- venting system improvements, such as direct venting

- building/heating system interaction and control

- education and technology transfer to ensure optimal selection, use, and maintenance of oil heating equipment.

While the list of items above seems to include problems widely varied in scope, a coherent plan combining fundamental and applied research on all combustion equipment technology can bring about marked improvement in most of the areas. The following chapter will, by way of introduction to such a plan, discuss the technical problems encumbering oil-fueled equipment research. 


\subsection{TECHNICAL BACKGROUND}

This chapter describes, from a long-term perspective, the technical problems that form the basis for program needs in oil-fueled equipment. It serves as a technical introduction to the program.

\subsection{CURRENT STATUS AND PROGRAM THRUST}

The bar graphs in Figure 4 illustrate the relative capabilities of oilfueled equipment in steady-state, in actual use, and after a period of continued use. Because of their relatively slow turnover, currently operating oil-fired boilers and furnaces average about $70 \%$ to $75 \%$ efficient in steady state, while new equipment averages $75 \%$ to $80 \%$ efficiency, and the very best new equipment may reach $85 \%$ efficiency. The potential efficiency in steadystate operation, however, could be as high as $95 \%$. Furthermore, as Figure 4 shows, none of the existing equipment provides anywhere near these efficiencies in actual operation, because of losses from on-off cycling and from degradation in performance over time. The fundamental long-term need is for higher net (operational) efficiency. Research must therefore explicitly address ways to decrease these operating efficiency losses, as well as improve the base, steady-state conversion efficiency.

The goal of this program is to address key technical barriers to improved efficiency in three major equipment types. First, there are a number of loss reduction possibilities in fixed-firing-rate (conventional) equipment. Second, there are important problems with low fixed-firing-rate equipment. Finally, there are a wide range of research problems for variable-output equipment, including the problem of what type of variable-output equipment would be most effective.

The remainder of this chapter will outline the technical barriers to developing and using advanced, high-efficiency equipment, and note the possible improvements that can be made in more conventional equipment by a particular technical advance. The barriers will be treated in an order roughly paralleling the type of research required--from the most fundamental to the most applied. Thus, fuel oil combustion and combustion diagnostics come first, 


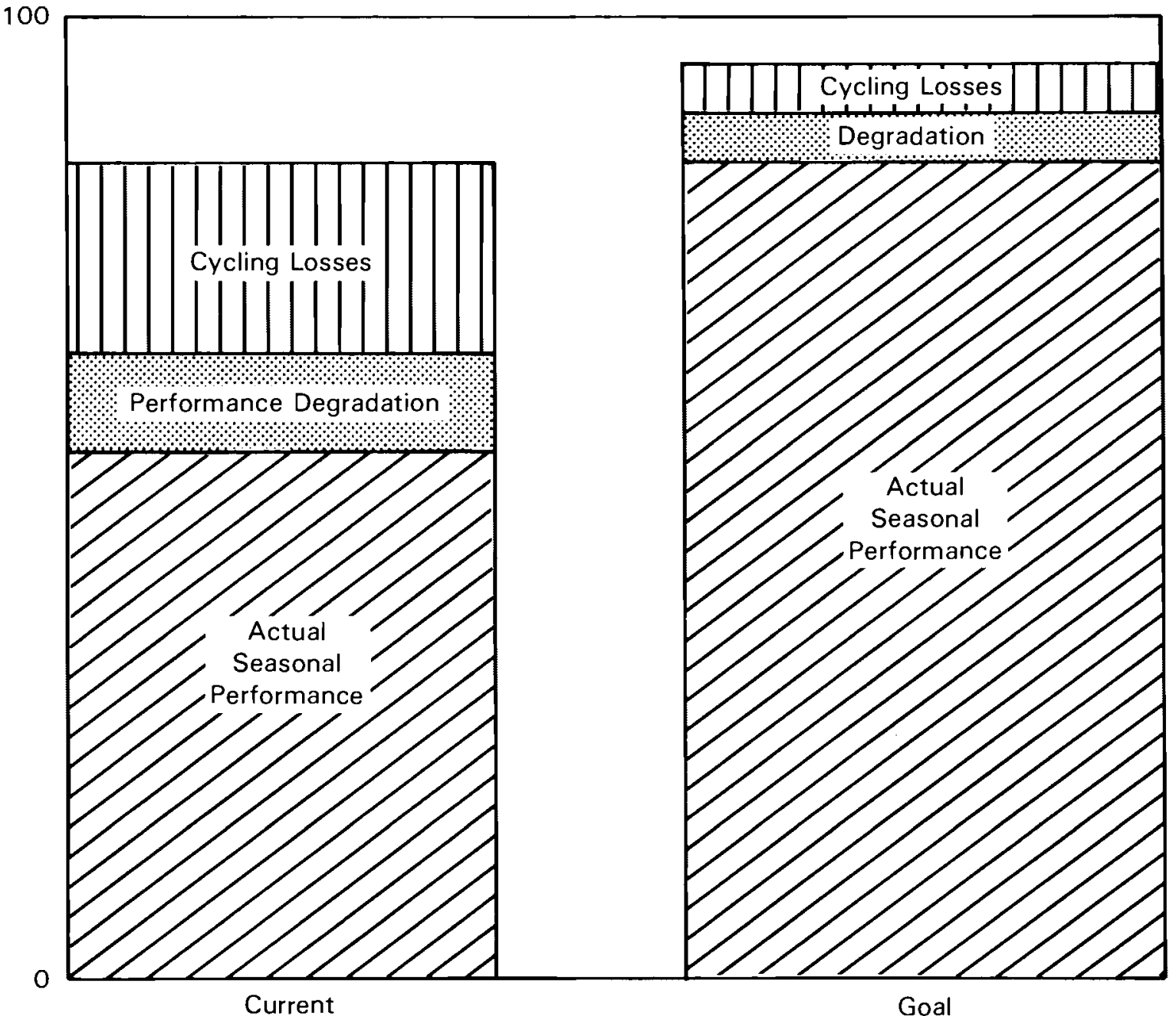

Primary Focus of Research Elements:

Steady-State Improvements -- Advanced heat exchangers, advanced combustion systems.

Seasonal Performance Improvements -- Fuel oil combustion, oil burner diagnostics, advanced heat exchangers, improved venting systems, advanced combustion systems, advanced equipment control strategies.

Performance Degradation Improvements -- Fuel quality, oil burner diagnostics, education, advanced equipment control strategies.

\section{FIGURE 4. Qualitative Performance Improvements}


followed by heat exchangers, controls, venting strategies, fuel quality, and equipment maintenance and installation.

\subsection{TECHNICAL PROBLEM AREAS}

Fuel 0il Combustion

Understanding the process of $0 i 1$ combustion is essential to all advanced research in this field. A key element in the combustion process that influences overall performance is vaporization of the liquid fuel oil before fuel/air mixing and ignition. Conventional oil burners typically rely on highpressure atomizing nozzles that produce a spray of small fuel droplets. These droplets begin to evaporate, forming the fuel vapors necessary for rapid dissociation of the hydrocarbons and chemical reaction with the oxygen contained in combustion air.

One problem with pressure atomizing nozzles is that a range of droplet sizes is produced. Small fuel droplets completely vaporize before entering the combustion zone, but the larger droplets do not. These larger fuel droplets contribute to incomplete combustion and smoke formation by oil flames, particularly in older furnaces. This can cause soot deposits on heat transfer surfaces of the boiler or furnace, which reduce the overall efficiency of the heating plant. Excess combustion air is then required to reduce smoke formation, and this also can lower efficiency. The severity of the problem varies according to burner design; some examples are burners with vigorous air swirl that creates internal recirculation patterns (i.e., flame retention burners) and burners with exhaust gas recirculation that can operate with lower smoke levels than other burner types.

Other operating limitations also are imposed by pressure-atomizing nozzles. The lowest practical fuel firing rate is limited to about 0.5 gallons per hour because the nozzle orifice becomes extremely small below this flow rate and can easily become plugged. This firing rate is too high for many applications, and can degrade the efficiency of the heating system. In addition, low firing rates reduce heat exchanger size and cost and permit development of more efficient systems. A further limitation of pressure-atomizing nozzles is that the fuel flow rate cannot be easily varied, while 
variable-firing-rate burners would improve efficiency by reducing off-cycle heat loss and by permitting variable heat outputs for zoned heating applications.

Fuel/air mixing is another important requirement for fuel oil combustion that can impact overall efficiency. Combustion air swirl, recirculation, and other basic physical occurrences within oil flames can have an important effect on smoke formation and on the amount of combustion air that is required. Changes in combustion air supply caused by seasonal variations in chimney draft and changes in air density can impact smoke production and equipment efficiency. In addition, strong fuel/air mixing forces, accompanied by large pressure drops across the burner head, tend to reduce burner off-cycle heat losses.

Transient effects that occur during burner startup and shutdown can cause smoke formation and efficiency degradation by soot accumulation. The details of this smoke formation mechanism are unknown. The severity of this problem depends on physical interactions during flame ignition, including the rapid volumetric expansion of combustion air following ignition.

Diagnostics

Improved diagnostics and monitoring methods are critical to the successful development and sustained use of advanced equipment. The major problem in this area is smoke. Excessive smoke causes soot deposits on internal heat transfer surfaces. This reduces heat transfer efficiency and produces elevated exhaust gas temperature, increasing fuel consumption. Studies have shown increased fuel consumption rates of $5 \%$ to $10 \%$ for moderate smoke levels. Smoke production in oil flames is usually controlled by increasing the combustion air supply. However, excess combustion air also reduces efficiency. Optimal burner adjustment, a delicate balance between smoke formation and excess air, varies with burner design and is determined in the field during oil burner installation and periodic servicing.

Existing smoke measurement and burner adjustment methods could be improved significantly by advanced measurement techniques. The smoke measurement procedure that is currently used was developed several decades ago and it is time consuming, which discourages its widespread use. The procedure uses a 
hand-operated pump that draws a sample of flue gas through a piece of filter paper to determine smoke density. This measurement is performed only by service technicians during burner servicing, and changes in the fuel/air ratio that can occur between service calls will go undetected by the homeowner for an extended time period. This represents a preventable source of inefficient fuel use.

Heat Exchangers

The development of an improved heat exchange component will be a central factor in the design of improved oil heating equipment. Conventional heat exchangers in boilers and furnaces result in significant heat loss during both steady-state and transient operation. Boilers and furnaces transport energy from the hot flame gases to the water, steam, or air that is used for space heating. Generally, the overall heat transfer resistance is dominated by the hot gas film coefficient and the warm air or hot water film coefficient. These coefficients directly limit the overall heat transfer rate for the boiler or furnace. Typical heat transfer coefficients are quite low (in the range of $\left.2 \mathrm{Btu} / \mathrm{h} / \mathrm{ft}^{2} \cdot{ }^{\circ} \mathrm{F}\right)$, meaning that the equipment must be quite large to produce the desired heat output.

Some heating systems with improved design features have begun to appear on the market, but many of these units continue to use conventional construction and venting technologies. Research is needed to examine innovative heat exchange processes and devices that may be applied to improve the overall efficiency of oil-fired space heating equipment. A key technical limitation for oil systems, however, is smoke formation that can restrict the applicability of equipment advances such as those already developed for gas equipment. Many design alternatives have been suggested, but nearly all of them have fundamental problems including high pressure drops, flow stability, corrosion, materials required for construction, complexity of construction methods, noise levels, overly small dimensions of flow passages, and soot deposition. Control

The development of viable control strategies for regulation of oil-fueled equipment, a difficult problem currently treated only very crudely, has two 
aspects: the thermal dynamics of the building in which the equipment is installed, and the thermal behavior of the equipment itself. Each of these aspects involves difficult problems about which little is known; in addition, there are problems associated with the interaction of the two. Because some of these problems are better treated under other elements of the DOE Building Equipment Research Program (BERP), the discussion here will be restricted to control technology for the conversion equipment, rather than building dynamics.

The control system of an oil-fueled equipment system responds to the equipment's operating environment. That environment consists of the air around the equipment jacket, the equipment's flame medium, the air or water side that is being heated, and the exhaust system. All of these have varying temperatures and flow and heat transfer rates (Berlad 1980). The control system balances these processes and the combustion/burner operation to maintain safety and desired outlet air or water conditions, and at the same time to maximize overall efficiency. The control system must therefore link the performance of a11 the equipment components, including proposed advanced elements.

Venting Systems

Conventional oil-fired heating system designs use a chimney for venting combustion product gases to atmosphere outside of the building. Heated exhaust gases enter the base of the chimney and rise, creating a negative pressure (i.e., draft) at the chimney inlet. From the standpoint of energy, however, current chimney design suffers from several important disadvantages.

When the burner starts, the chimney is cool and produces less draft; this affects the burner fuel/air ratio, contributing to smoke production and efficiency loss. Chimneys, typically of large thermal mass, remain hot after the burner goes off. Off-cycle draft then continues to pull cool air through the heating unit, removing some of its stored heat. Studies at Brookhaven (Batey et al. 1979) and other research agencies have found that off-cycle heat loss can increase annual fuel use by $15 \%$ in some systems.

A second important source of chimney-related heat loss is the dilution air required for draft control. Typically, a barometric damper is installed that automatically admits cool room air into the exhaust flue to maintain a constant 
chimney draft. This air (and the combustion air) is often taken from heated building space and replaced by infiltration of cold outdoor air. In the majority of in-place systems, a minimum temperature of about 300 to $350^{\circ} \mathrm{F}$ is required to produce adequate chimney draft for proper venting, and also to prevent corrosion damage from flue gas condensation. Use of chimneys is therefore a strict limitation on possible equipment improvements such as condensing or pulse combustion operation. Furthermore, in addition to the technical problems involved in developing alternative venting systems, there are strict safety codes and other institutional barriers that will have to be overcome or taken into account. The extent of these barriers is not fully specified at present, although a brief review has been undertaken at Brookhaven.

\section{Fuel Quality}

Fuel oil properties and their degradation during storage can have an important impact on fuel atomization, vaporization, and combustion, in turn directly affecting thermal efficiency and pollutant emissions. The current standard for fuel oil properties is the ASTM D-396 specification for fuel oils. This standard sets acceptable limits for many key physical properties of fuel oil produced by oil refiners for use in residential and commercial heating equipment. Variations from these standards can cause burner performance problems. Fuel quality degradation during storage in residential and commercial fuel tanks can also produce problems that include losses in heating system efficiency because of contamination by water or biological agents or because of sludge formation. These effects can range from efficiency degradation to equipment malfunction and breakdown. Fuel analysis studies conducted by the DOE have shown a recent decrease in some key fuel oil properties, (a) and this is becoming a major concern to the industry because of potential problems with fuel burning efficiency and cleanliness.

(a) M. Gunn, personal communication, February 1986. 
Some key fuel properties that affect efficiency are listed below.

- Viscosity indicates resistance to flow. Increased viscosity can cause the production of larger droplets by pressure-atomizing fuel nozzles, which in turn contributes to smoke formation and lower efficiency.

- Distillation temperatures affect the temperatures at which the fuel oil components vaporize. Higher distillation temperatures can contribute to incomplete combustion and smoke formation.

- Pour point is a measure of the temperature at which the fuel stops flowing. High pour points can cause serious problems for above-ground fuel tanks that are subjected to low outdoor temperatures. Cold oil contributes to atomization problems and smoke production.

- Flash point indicates fuel volatility and has a direct impact on fuel storage safety and fire hazards.

Equipment Installation and Maintenance

0il-fueled equipment installation and maintenance are typically performed by heating oil distributors. As they are small, independently owned businesses, the typical level of technical sophistication is very low. Technical training programs within industry have focused on safe and reliable operation of the equipment. One case of carbon monoxide poisoning from poorly installed or adjusted equipment can ruin an oil distributorship. Because of this, energy efficiency and the role of installation and maintenance in achieving it are often poorly understood. This problem will be compounded by the more sophisticated and possibly more exacting equipment needed to achieve significant performance improvements. 


\subsection{RESEARCH PROGRAM ELEMENTS}

The long-term technical aim of this program plan is the development of advanced oil-fueled equipment concepts. A number of technical program elements have been developed that target the technical problem areas impeding progress toward this goal that were discussed in Chapter 5. In that chapter, the general character of each barrier was indicated. This chapter emphasizes how elements treating the barrier fit into development of new equipment concepts, as well as solve shorter-term problems that are of interest to industry. Figure 5 shows how the program elements cover all the major subsystems of oil-fired equipment as well as its operation.

This chapter consists of program descriptions for eight research elements. As is evident when viewing Figure 5 the research program elements cover aspects of almost every physical process occurring in oil-fired equipment, beginning with degradation of the fuel that is to be burned, and progressing through combustion, soot diagnostics, new heat exchanger concepts, and new methods of venting exhaust gases. It also includes system-level concerns: synthesis of advanced concepts and new methods of controlling the whole piece of equipment. An additional and vital element is education: the low-tech nature of current oil-fired equipment installation and maintenance must also be improved before new, highly efficient types of equipment will perform at their best. This will be done by first improving knowledge of current equipment, which has a significant energy impact by itself. Education is related to technology transfer of research results, which is an ongoing responsibility of all the research elements. These two activities are discussed as facets of one element in this plan.

\subsection{FUEL QUALITY}

Research Need

Research into the effects of fuel property variations on the fundamental combustion processes is necessary to establish an operating envelope for future equipment generations. Thus, it is important to quantify the effects of property variations on measurable combustion parameters, including efficiency. 

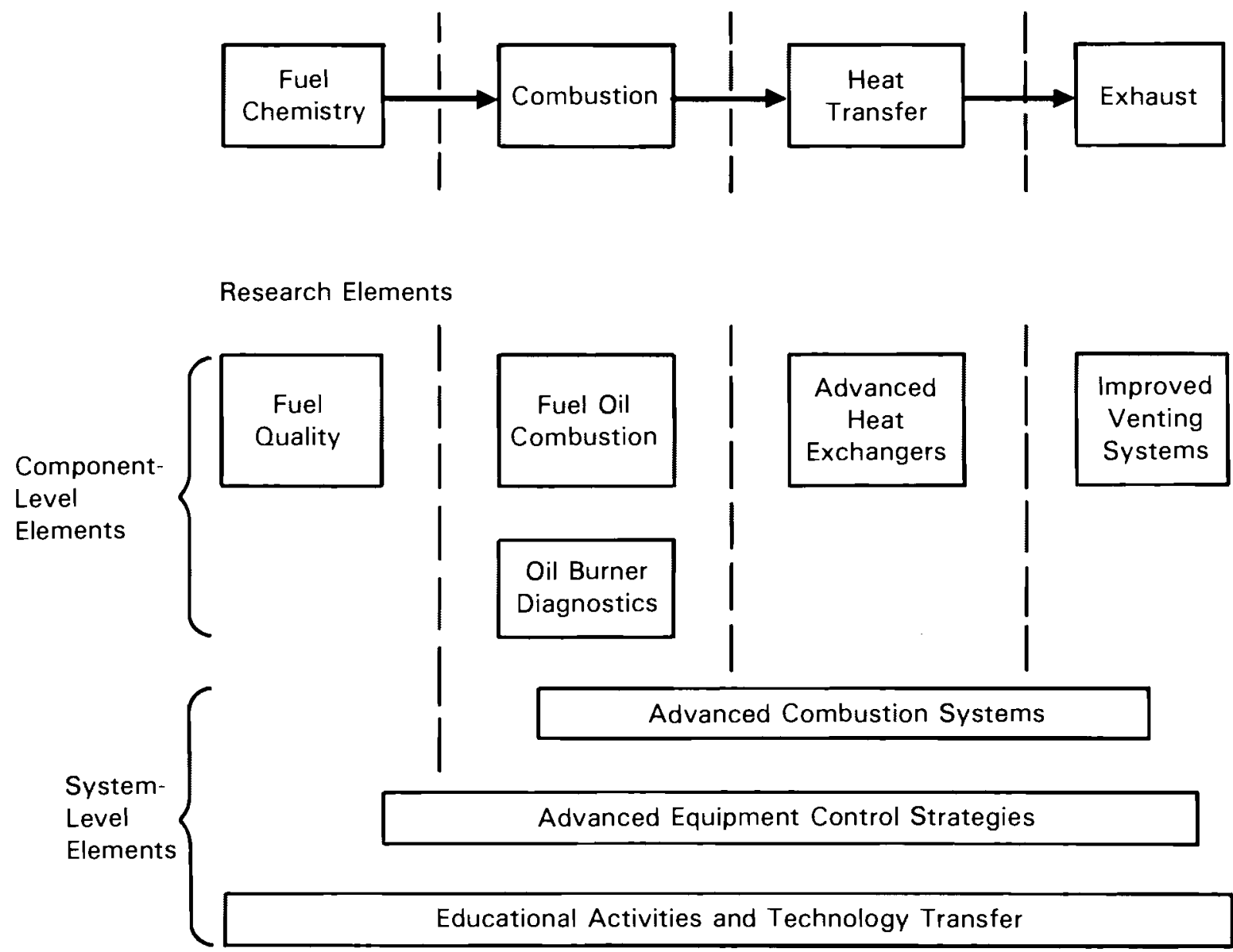

\section{FIGURE 5. Program Research Elements}

This problem is both a short- and a long-term one, as the fuel degradation (which is a current problem) as well as the varying feedstocks of the future are relevant. It is currently unknown what the exact effects of fuel degradation are, so guidelines for handling and burning degraded fuels are needed. Objectives

- Quantify the effect of fuel property changes on fundamental fuel oil combustion processes. 
- Apply these basic studies to various generic and advanced burner designs.

- Develop guidelines for burning off-quality fuels.

\section{Research Strategy}

This research is based on fundamental fuel oil combustion studies followed by applied research that extends the basic findings to a range of generic burner designs. The interaction of fuel storage practices or of feedstock chemistry changes with changes in basic fuel properties can then be quantitatively analyzed in terms of heating efficiency variation, soot production, etc. The results can then be used to assess future needs in this area for advanced system design purposes.

Technical Activities

In the laboratory, the impact of fuel quality changes on the micro- and macroscopic characteristics of oil flames will be investigated. Fuel parameters to be varied include viscosity, fuel temperature, distillation range variations, pour point, and fuel contamination by water, biological agents, and sludge. This investigation will involve a range of fuel atomization techniques (such as high-pressure, air, and ultrasonic) and a range of fuel/air mixing parameters that exist in conventional and conceptual oil burners.

\subsection{FUEL OIL COMBUSTION}

Research Need

Fuel oil combustion is a very complex process, far more difficult, for example, than natural gas combustion. It will not be the purpose of this research to develop a thorough understanding of this process, as it cannot be gained in an applications-oriented research project such as this. However, there are certain aspects of fuel oil combustion that demand fundamental knowledge to develop low- or variable-firing-rate burners. Such burner technologies are one of the keys to this project, and no fully workable concept has been developed so far. $0 i 1$ combustion involves getting the oil into a vapor phase and oxidizing it in a high-temperature reaction, but $0 i 1$ is composed of 
many different substances and does not handle well under these varying thermal conditions. Improved design rules on how these processes can be performed with oil are necessary.

Objectives

- Develop better functional understanding and improved techniques for fuel vaporization and atomization.

- Provide fundamental-level knowledge input on sooting, excess air requirements, and other important combustion parameters to fuel quality and diagnostics and heat exchanger work.

- Provide burner concepts for advanced generations of equipment.

\section{Research Strategy}

The research programs will be conducted as a combination of fundamental laboratory-scale studies, combined with practical test setups that simulate the range of operating conditions experienced in field-installed heating equipment. A great deal of important information must also come from research conducted under other programs at universities and at Sandia National Laboratory's Combustion Research Facility. These activities should focus on physical interactions occurring in oil flames and use this knowledge to work on effective vaporization and atomization approaches with low sooting and low excess air. Soot-free oil combustion is a key to the development of advanced highefficiency heating systems.

Technical Activities

Atomization techniques, fuel/air mixing and vaporization, sooting, and advanced burner concepts will be studied. Atomization research will examine various atomization approaches and their effects on the following important parameters:

- droplet size distributions

- droplet velocities and flow pattern

- pollutant emissions

- smoke production tendency 
- flow rate lower limits and variability

- stability.

Fuel/air mixing and vaporization studies will focus on droplet size effects, soot formation as a function of mixing parameters, recirculation effects, and flame stability under varying draft conditions. Work will be done to reduce the effect of combustion transients on overall performance with particular emphasis on smoke control techniques applicable to burner design. Finally, advanced burner approaches will be developed that have suitable low/ variable firing rates and low sooting.

\subsection{OIL BURNER DIAGNOSTICS}

\section{Research Need}

Fundamental research is needed to identify measurable parameters and their relationships as they reflect soot production and efficiency in flames. A key problem is to characterize the basic process of smoke and particulate formation within oil flames under varying operating conditions such as fuel droplet size, excess combustion air and fuel/air mixing intensity in relation to soot particle size and density. Furthermore, soot deposition rates on heating surfaces must be evaluated for both steady-state and transient conditions. Specific measurement approaches will be evaluated with respect to measurement accuracy, repeatability, cost, and correlation with the empirical smoke-spot tests that are currently used to adjust oil burners. This knowledge will form the basis for developing laboratory, field test, and in-equipment monitoring devices.

\section{Objectives}

- Develop and apply advanced combustion diagnostic and smoke monitoring techniques to oil-fueled equipment in the laboratory.

- Develop concepts for field test devices and built-in monitoring use in equipment.

\section{Research Strategy}

Our understanding of basic combustion phenomena has increased in recent years and many new laboratory diagnostic methods have been developed to study 
combustion processes in more detail. Some of these advances are helping to develop a better understanding of oil flames, and they may form the basis for improved soot-free burner adjustments. Direct measurements of soot particulate density can be successful by using light scattering, ionization, corona discharge, and other techniques. Changes in flame emissivity and radiative heat transfer also have been investigated for advanced combustion controls in recent years. Work on this element will interact and develop strongly with the fuel oil combustion research element, as knowledge of the combustion process and of how to measure it go hand in hand.

Technical Activities

This element will study the fundamentals of soot production in oil flames through review of literature and interaction with ongoing research programs, and will identify specific measurement approaches to evaluate soot production. It will then conduct laboratory research to identify measurable parameters and their interrelationships as indicators of soot production. Examination of many of the soot measurement techniques identified earlier will be included. With this base of knowledge, selected advanced sensing techniques will be developed.

Specific analytic methods to be applied may include:

- laser diffraction techniques to evaluate fuel droplet size distribution

- laser Doppler velocimetry to study flame dynamics and the interaction of local air and fuel velocities

- infrared and ultraviolet spectroscopy to study flame radiation changes and their relationship to stoichiometry and soot formation

- flame radiometers to assess gross changes in radiative heat transfer from the flame as a function of free carbon concentration

- standard smoke measurement techniques that may be applied to oil flames, including light scattering, attenuation, and ionization methods

- gas and liquid chromatography to identify chemical compositions. 


\subsection{ADVANCED HEAT EXCHANGERS}

\section{Research Need}

Some heating systems with improved design features have begun to appear in the marketplace, but many of these units continue to use conventional boiler construction and venting technologies. Advanced heat exchangers and chimneyless operation may offer the potential for improved seasonal efficiency into the 95 percent range at a reduced equipment cost because of improved heat transfer, which results in fewer required materials for construction of the smaller units. This is especially likely for possible low-capacity furnaces and boilers which will require new heat exchanger approaches. These innovations may be applicable to both the new and retrofit oil heating equipment markets.

Objectives

Heat exchanger concepts that will attain or include:

- enhanced heat transfer rates for smaller units

- optimized heat exchanger mass to minimize on-cycle and off-cycle losses

- variable area design approaches for use with variable output burners

- advanced materials for high efficiency and reliability

- reduced flue gas temperatures to increase steady-state efficiency

- condensing flue gas operation to recover some of the latent heat of vaporization of the combustion gases

- low equipment costs (consistent with reduced heat exchanger size) to enhance market penetration.

\section{Research Strategy}

A number of innovative heat exchange processes and devices that may be applied to improve the overall efficiency of oil-fired space heating equipment will be examined. Some of the recent natural gas equipment developments by the DOE and the GRI may be adaptable for oil heat applications, reducing the level of effort required for this research program. A key technical limitation for 
oil systems, however, is smoke formation that can restrict the applicability of equipment advances developed for gas. There will be strong interaction between heat exchanger and the oil combustion and oil burner diagnostics work elements. Technical Activities

Work will begin with assessment of literature on a large number of heat exchanger concepts. Certain promising ones will be developed into experiments to determine their performance under varying heat transfer conditions and in oil flame gases. Some candidate heat exchange concepts include the following:

- Compact heat exchangers constructed of conventional boiler and furnace materials but designed for higher heat transfer rates and smaller size.

- Heat pipe exchangers that permit reduced equipment size, and that have been used in the design of new, high-efficiency, gas-fired heaters.

- Catalytic exchangers that incorporate surface combustion and heat transfer.

- Direct contact heat exchangers in which the flame gases and heat transfer medium are in direct contract, which is the technique currently used in a recently developed add-on heat exchanger for boilers and furnaces.

- Extended surface heat exchangers that may feature a soot-destroying surface to reduce performance degradation over time.

- Particle-assisted heat transfer found in fluidized-bed heat exchange whereby particle action prevents boundary layer growth, improving heat transfer rates.

- Acoustically enhanced heat transfer that uses sound waves to increase overall heat transfer coefficients.

- Pulsed flow systems that enhance heat transfer rates (as demonstrated in natural gas pulsed combustion systems). 


\subsection{IMPROVED VENTING SYSTEMS}

Research Need

Improved venting systems to replace chimneys are an important technological need for oil-fueled equipment. Efficiency improvements of 10 to 20 percent are expected, and the reduced cost of some venting alternatives can reduce the total cost of the heating system. Equally important is the virtual necessity of vastly improved venting to permit successful development of advanced oilfueled equipment concepts, such as condensing and pulse combustion systems. Objectives

- Determine the effects of exhaust gas velocity, outlet configuration, building-induced flow patterns, and wind speed and direction on venting.

- Identify negative impacts resulting from low-elevation exhaust such as building surface discoloration and pollutant emissions.

- Define the minimum venting requirements of existing and new technology oil heating equipment.

- Provide the technical basis for voluntary codes and standards.

\section{Research Strategy}

The strategy for this element will focus first on direct venting techniques for current equipment. Sufficient tests and analyses will be performed to identify important design parameters for direct vent systems, and establish design rules. Once application of direct venting to current systems is possible, work on its use with advanced systems will continue.

\section{Technical Activities}

New venting approaches will be experimentally evaluated, with key venting parameters in mind, using both forced-draft and induced-draft conditions. Tests will investigate the impact of draft conditions and wind-induced variations on the combustion process. The perceived advantages of direct venting, such as reduced heat losses and reduced transient effects, will also be evaluated. The results of the laboratory tests will be used to develop computer 
models for venting to be used in conventional system design and in advanced system concepts research, and to develop simple, generic design recommendations for direct venting systems. This will include analyses performed to determine the optimal ranges of exhaust venting parameters--required negative pressure, exhaust gas flow rate, and operating temperature--for both existing and new heating units.

\subsection{ADVANCED COMBUSTION SYSTEMS}

Research Need

New processes such as pulsed and catalytic combustion, and new approaches such as variable or low firing rates, can improve the efficiency of oil heating systems and permit the development of a new generation of heating equipment. This element includes investigation of such concepts and approaches as well as eventual synthesis of a variable output proof-of-concept device from the work in other research elements in this project. Improvements to equipment performance may include more complete combustion, reduced pollutant emissions, enhanced heat transfer rates, lower on-cycle and off-cycle heat losses, reduced boiler and furnace sizes for reduced heat loss and lower costs. Recent research and development activities on pulsed combustion systems for natural gas heating have produced a number of promising heating devices with substantially higher thermal efficiency than conventional systems. Catalytic gas heaters are also being developed that permit new design concepts, including zone heating units distributed throughout the building.

Objectives

- Assess need for low-firing-rate modulating or staged burners.

- Identify advanced combustion techniques including those using pulsed and catalytic combustion.

- Develop computer modeling and system design approaches to permit incorporation of the latest technical knowledge of particular physical effects into a synthesized combustion system concept. 
- When sufficient results from other program elements are available, begin to develop one or more laboratory prototypes for experimentation.

Research Strategy

As introduced in the problem statement, this research element will focus on new system concepts. In early stages it will primarily include analysis. The analysis tools developed will be vital to the later stages, during which hardware research and proof-of-concept design of a new generation of equipment will occur.

\section{Technical Activities}

This research element will first involve a review and assessment of current research on advanced combustion techniques. Relevant computer codes will be acquired, and experiments will be performed as necessary to investigate the specific applications. Computer modeling approaches will be developed for the most promising types of complete systems. This research element will integrate results both from other elements of this project, from results of other DOE research currently conducted by the Energy Conversion and Utilization Technologies Program (ECUT), and from non-DOE research.

\subsection{ADVANCED EQUIPMENT CONTROL STRATEGIES}

Research Need

There currently exists little or no variable or low-firing-rate oil-fueled equipment technology. This is largely a function of the need for fundamental understanding of oil combustion. It also means that there is a lack of knowledge of strategies for controlling such equipment. This research element focuses on how oil-fired equipment thermal dynamics should be handled by an advanced control system to produce optimal operating efficiency.

Objectives

- Control algorithms or strategies accounting for dynamics of equipment heat exchange, heat loss, venting, and variable firing. 
- Control approaches suitable for advanced concepts, including catalytic and pulse combustion.

- Overall dynamic computer models suitable for use in equipmentdistribution and equipment/building dynamic simulations.

- Concepts for "smart" microprocessor control systems.

Research Strategy

The focus of this work is on the dynamics of the oil-fired equipment itself. As unsteady heat transfer is a challenging field that is not quite reduced to practice, the work will include considerable interaction with heat transfer research. Much of its driving force, however, will come from hightechnology, "smart" control systems based on microprocessors. These devices, now common in home appliances, can cheaply and effectively make complex control decisions, and can even interact with intelligent building thermal control systems.

Technical Activities

This research element will involve performing very thoroughly instrumented, dynamic experiments on an operating furnace and/or boiler. This will capture the details of thermal interactions over time, subject to forced changes in operating conditions. Dynamic computer codes and models will be developed to analyze advanced control concepts and strategies that will permit optimal thermal performance under all conditions. Simple dynamic models will be written for use in system simulations. Finally, this knowledge will be implemented in microcomputer control algorithms for conceptual system(s) being developed by the project.

\subsection{EDUCATIONAL AND TECHNOLOGY TRANSFER ACTIVITIES}

Need

Education and technology transfer are not strictly research activities, but they are very important to the program's success. Educational activities are important for two reasons. Conventional oil-fueled systems, though technically simple, require considerable attention in order to perform at their 
best. Educational mechanisms, if encouraged and coordinated, can lead to a near-term gain in efficiency and concurrently build up the technical sophistication of the maintenance industry. This will be critical when the new, more complex technologies under development in this program are eventually incorporated into products by industry.

Technology transfer is viewed here as both obtaining private sector and state and local government input into R\&D planning and facilitating the use of R\&D results by users. This plan represents the culmination of a great deal of input into oil-fueled equipment plans by many different groups. Ongoing efforts to focus concerns of all groups involved are needed, however. Various strategies must be taken to provide effective transfer of research results. Some strategies (e.g., conferences) must be planned to interact effectively with educational activities. Perhaps the key to the technology transfer work is that it must be integral to each research element.

Objectives

- Coordinate educational/training resources for important audiences-service technicians, contractor/builders, installers.

- Facilitate opportunities for researchers, manufacturers, service people, and end users to communicate concerns that are important to current and future types of equipment.

- Effectively communicate program results to manufacturing, oil marketing, and regulatory decision-makers.

- Establish a central source of technical information on oil heat.

Strategy

DOE involvement in this area should have a high impact at reasonable cost because of its visibility. The DOE role will be one of coordination and facilitation, providing opportunities for communication from experts to others and between experts themselves. The educational activities should coordinate with and considerably enhance technology transfer by upgrading the visibility and activity level of technical work in this area. 
Activities

The primary activities in this program element will be to hold workshops, conferences and other types of meetings, to produce educational/training materials, and to collect and process information on oil heating research and industry. Information transfer may include targeted meetings with key industry decision-makers, government/industry cooperative projects, selection of innovators and leaders for special partnerships, special coordination with trade associations, and even promotion of end-user demand. 


\subsection{PROGRAM RESOURCES AND MANAGEMENT}

This chapter outlines program management and preliminary resource plans.

\subsection{MANAGEMENT STRUCTURE}

The oil-fueled equipment project is one of several key elements of the Building Equipment Research Program (BERP), which is in the Office of Buildings and Community Systems in the Department of Energy. A decentralized management plan is used in BERP, whereby the technical resources of the national laboratories are used for program management functions and performing research, while program direction and policy-making is the responsibility of DOE headquarters.

Brookhaven National Laboratory has program management responsibilities for the oil-fueled equipment research. Brookhaven will issue Requests For Proposals, evaluate proposals, execute contracts and monitor contractor performance, and otherwise perform the bulk of the interaction with universities and manufacturers. It will also perform a variety of in-house research that it is best suited to do, and coordinate technology transfer on work done in-house and by others. Finally, Brookhaven will continually interact with DOE headquarters, serving as the primary information channel for program control as well. This activity is typical for BERP and other DOE research programs.

\subsection{MANAGEMENT APPROACH}

The oil-fueled equipment technology program outlined here is planned and managed to complement private sector initiatives. Operationally, this means maximizing industry involvement, with DOE national laboratories serving in management, testing, and research roles, and universities providing critical knowledge and fundamental research as well. Industry involvement is important for three reasons. First, industry is the appropriate place for hardwareintensive research, and many of the technical questions to be answered about oil-fired equipment involve working with hardware. Second, transfer of technology to industry is far more effective if industry is involved with the work from the beginning, either performing research or observing and providing feedback. In this project, each research area will include work on transferring 
the technology, starting in the early stages. Finally, there are a great many codes and standards applicable to oil-fired equipment, many of which can even affect applied research decisions. Manufacturers, who are well aware of these pitfalls, must help in generating awareness of such institutional and market factors.

The DOE national laboratory involvement covers the full range from basic research to doing tests on conceptual hardware. Most important, though, is the labs' role as research managers: making sure the right projects are being done, and by the right people. In this project this role is especially important, as much of the technological advancement will be borrowed from related fields, including both basic research fields and work done on gas heating equipment. The multiprogram national labs have the unique ability to work across fields in this way, and to make this approach effective.

The university involvement will be stimulated by well-thought-out requests for proposals and cooperation originating at Brookhaven. Not only will the university research directly aid in development of new technology, but the training of graduate and undergraduate students in the field will upgrade the technology in the long term. Universities are an integral part of this program.

\subsection{RESOURCES}

This project as outlined will develop a large number of improvements to current capabilities of oil-fired equipment and its use. Some of the planned improvements should be completed within one or two years; others will take longer. The eventual goal of the program, one or more complete new equipment concepts, should take 5 to 8 years. All work is expected to take place within a funding scenario of approximately $\$ 2$ million per year in real dollars. Funding on specific research elements is expected to shift somewhat as various stages on the various elements progress and trade off against one another. Figure 6 outlines the projected phasing of the various research elements. Explicit milestones have not been set at this stage, but should be developed early in the work on each particular element. 


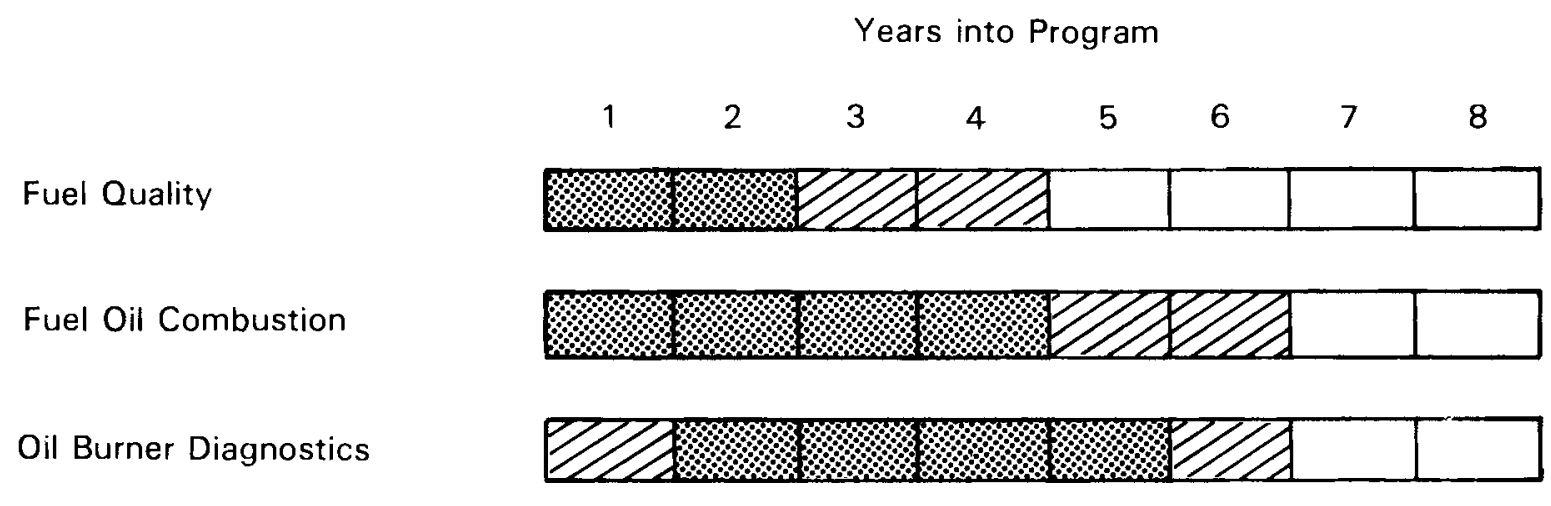

Advanced Heat Exchangers

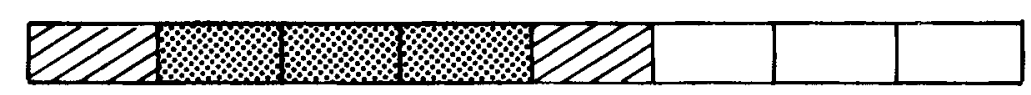

Improved Venting Systems

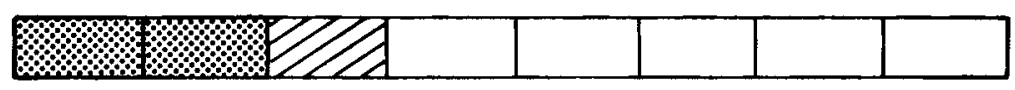

Advanced Combustion Systems

Advanced Equipment Control Strategies

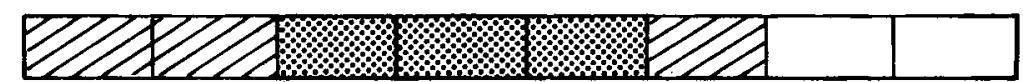

Educational Activities

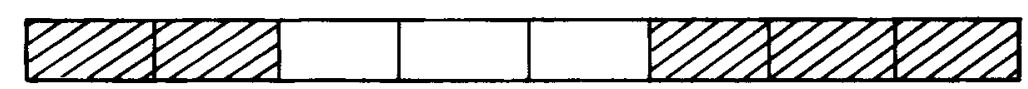

Technology Transfer
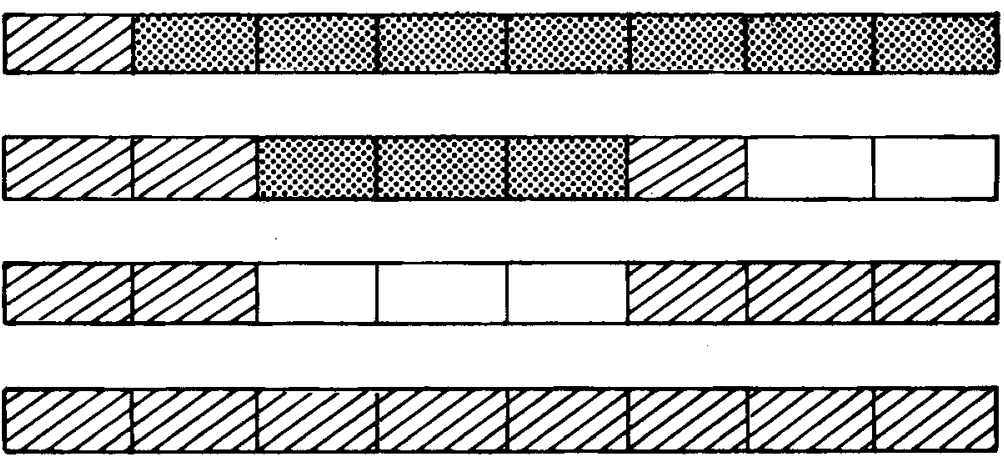

-Major Effort - Experiments, Hardware, Analysis

Q7 -Minor Effort - Minor or Preliminary Effort - Analysis, Assessments

-Little or No Effort

FIGURE 6. Possible Research Element Phasing 


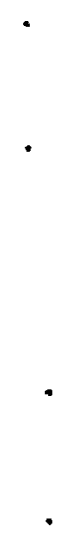

. 


\subsection{REFERENCES}

Andrews, J. W. 1986. "Impact of Reduced Firing Rate on Furnace and Boiler Boiler Efficiency." ASHRAE Transactions, Vol. 92, p. 1.

Andrews, J. W. A Research Agenda for Space Conditioning. BNL-51744, Brookhaven National Laboratory, Upton, New York.

Ball, D. A., et al. 1982. Condensing Heat Exchanger Systems for Residential/ Commercial Furnaces and Boilers, Phase I and II. BNL-51770, Brookhaven National Laboratory, Upton, New York.

Batey, J. E., et al. Reduction of Residential Fuel 0il Consumption by Vent Dampers. BNL-26467, Brookhaven National Laboratory, Upton, New York.

Battelle Columbus Laboratories. 1982. 1982 Symposium on Condensing Heat Exchangers, Atlanta, Georgia, Proceedings, Volume II. GRI-82/0009.3; PB82240078, National Technical Information Service, Springfield, Virginia.

Berlad, A. L. Nature and Utility of Some Unsteady Characteristics of a FossilFuel-Fired Boiler. BNL-51108, Brookhaven National Laboratory, Upton, New York.

DOE-Buildings and Community Systems. 1985. Overview of Building Energy Use and Report of Analyses--1985. DOE/CE-0140, Washington, D.C.

Energy Information Administration. 1984. Residential Energy Consumption Survey: Consumption and Expenditures, April 1982 Through March 1983. DOE/DIA$0321 / 1(82)$, Washington, D.C.

Energy Information Administration. 1985. Petroleum Marketing Monthly: September, 1985. DOE/EIA-0380(85/09), Washington, D.C.

Locklin, D. W. 1960. Recommendations for an Industry-Wide 0il-Burner Research Program. Battelle Memorial Institute, Columbus, Ohio.

Locklin, D. W. and H. R. Hazard. 1980. Technology for the Development of High-Efficiency 0il-Fired Residential Heating Equipment. BNL-51325, Brookhaven National Laboratory, Upton, New York.

Mariano, C. F. 1982. A Low Input, Variable Firing Rate, 0il-Fired Burner. BNL-51558, Brookhaven National Laboratory, Upton, New York.

Razgaitis, R., et al. 1984. Condensing Heat Exchanger Systems for Residential/Commercial Furnaces and Boilers, Phase III. BNL-51770, Brookhaven National Laboratory, Upton, New York. 
Razgaitis, R., et al. 1985. Condensing Heat Exchanger Systems for Residential/Residential/Commercial Furnaces and Boilers. BNL-51943, Brookhaven National Laboratory, Upton, New York.

Schipper, L. and A. N. Ketoff. 1985. "The International Decline in Household 0i1 Use." Science 230:1118.

Schladitz, H. J. 1982. Development of the Schladitz 0il Burner. BNL-51549, Brookhaven National Laboratory, Upton, New York.

Thermacore, Inc. 1982. Development of a High Efficiency Warm-Air Furnace Using Heat-Pipe Principles. BNL-51622, Brookhaven National Laboratory, Upton, New York.

Woodworth, L. M. and G. Dennehy. 1981. Space Conditioning Equipment Technology--A Progress Report on the Brookhaven National Laboratory Program. BNL-51403, Brookhaven Nationa1 Laboratory, Upton, New York. 
APPENDIX A

PROGRAM ENERGY SAVINGS 


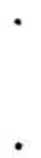

.

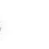


APPENDIX A

PROGRAM ENERGY SAVINGS

This appendix provides estimates of program energy savings once the oilfueled equipment program is completed. The estimates are made by research element. They assume successful results of a particular element, and the use of these results in designing or operating a certain fraction of the new equipment or retrofit assemblies made and sold. This new equipment's improved performance is estimated, as is its market penetration. Because oil-fired equipment is long lasting, it takes a long (but very uncertain) time to achieve sizeable market penetrations. Using all the above estimates, a figure is given for possible energy savings due to a particular technological improvement. Estimates for the various elements cannot necessarily be added up to show cumulative savings, because they overlap on the technical level.

Given the uncertainties in both fuel savings and market penetrations, however, simply rounding off the total savings number can give a good rough savings number. This is justified by assuming that the improvements, although overlapping technically, each penetrate different portions of the equipment market. This is the likely scenario, as manufacturers seldom wish to embrace too many new technologies with a single product.

The worksheet on the following page provides details of the energy savings calculations. Venting, diagnostics, controls, and education provide the bulk of energy savings in the 2000 to 2010 time frame because of their large market penetrations. The major fuel savings provided by the heat exchanger and the advanced systems elements will be increasing their market share rapidly at that point, however. This worksheet shows that in round numbers, savings from the program 5 to 15 years after program completion will be 0.25 quads ( 2 billion at $\$ 1 /$ gallon oil) per year. 
TABLE A.1. Annual Energy Savings After Program Completion--Residential Sector

(1)

Estimated

Fuel

Savings

Item
(4)

Estimated

Market

Penetration

(\%)

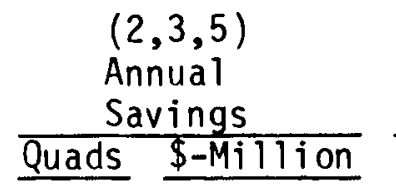

Quads
(6)

Cumulative Savings Over 20 Years

\section{RESEARCH ELEMENT}

1. Improved Venting Systems

15

2. Advanced Heat Exchangers

27

3. 0i1 Burner Diagnostics

4. Fuel Quality

5. Fuel 0il Combustion

6. Advanced Equipment Control Strategies

7. Advanced Combustion Systems

EDUCATION/TECHNOLOGY TRANSFER

16

\section{5}

5

12

15

32

5

0.02

0.04

292

0.81

5,844

10

0.03

212

0.59

4,235

0.04

292

0.81

5,844

10

0.01

39

0.11

779

10

0.01

94

0.26

1,870

0.04

292

0.81

5,844

50

0.09

123

0.34

2,461

TOTALS (assuming no technical overlaps)
0.2
1,974
5.47
39,484

NOTES: (1) Percent savings estimated based on average efficiencies of existing equipment.

(2) Based on annual fuel oil consumption of 1.08 quadrillion BTUs per year.

(3) $11,100,000$ oil boilers and furnaces now being used for central heating.

(4) Estimated market penetration after the R\&D program is completed (2010).

(5) Annual savings are calculated based on present energy use, percent savings, and percent market penetration; oil at $\$ 1.00$ per gallon.

(6) Cumulative savings are projected based on an expected equipment lifetime of 20 years. 


\section{DISTRIBUTION}

No. of

Copies

OFFSITE

30 DOE Technical Information Center

R. Albrecht

NYSERDA

2 Rockefeller Plaza

Albany, NY 12223

American Boiler Manufacturers Association

1500 Wilson Blvd.

Arlington, VA 22209

American Petroleum Institute

2101 L St. NW

Washington, DC 20037

J. Andrews

Brookhaven National Laboratory

Building 20

Upton, NY 11973

J.-M. Bader

CETEC - Centre de Recherche Elf de Solaize

Boite Postale 22

69360 Saint Symphorien d'Ozon

France

J. Batey

Steven Winter Associates, Inc. 6100 Empire State Building

New York, NY 10001

N. Bianco

Whale 0il Corp.

1 Coffey Street

Brooklyn, NY 11231

A. Boiarski

Battelle Columbus Laboratories

505 King Avenue

Columbus, $\mathrm{OH} 43201$
No. of

Copies

T. T. Bramlette

Sandia National Laboratories

P.0. Box 969

Livermore, CA 94550

A. Brand

Hart \& Iliff Fuel 0il Company

4 Hampton Street

Newton, NJ 07860

M. F. C. Brooker

Aero Environmental Limited

37 Hanna Avenue

Toronto, Ontario M6K $1 \times 2$

Canada

P. Brzescinski

Patterson 0il Energy Group

185 Magnolia Avenue

Floral Park, NY 11001

T. Butcher

Brookhaven National Laboratory

Building 120

Upton, NY 11973

15 D. Cahoon

Vice President for Policy

Petroleum Marketers Assn. of America

1120 Vermont Avenue, N.W.

Suite 1130

Washington, DC 20005

S. Chakrawarti

R. W. Beckett Corporation

P.0. Box 1289

Elyria, $\mathrm{OH} 44036$

C. K. Chu

General Services Administration 26 Federal Plaza

New York, NY 10278 
No. of

Copies

COMBUSTION INSTITUTE

986 Union Trust Building

Pittsburg, PA 15219

J. R. Cunningham

Thermo Products, Inc.

P.0. Box 217

North Judson, IN 46366

5 D. Day

U.S. Department of Energy 150 Causeway St.

Boston, MA 02114

T. de Chiara

The Tankit Corporation

515 Lehigh Avenue

P.0. Box 795

Union, NJ 07083

D. Durkin

Durkin Fuel

88 North Main Street

Brewster, NY 10509

D. W. Engblom, Vice-President. Yukon Energy Corporation

378 W. County Road D

New Brighton, MN 55112

G. Fanelli

Ford Products Company

Ford Products Road

Valley Cottage, NY 10989

L. Fisher

Vice-President, Engineering

The Carlin Company

601 Marshall Phelps Road

Windsor, CT 06095

J. A. Fitzgerald

Burnham Corporation

38 Miller Road

West Farmingdale, NY 11735
No. of

Copies

W. F. Foster

Seymour 0il Company

150 Day Street

Seymour, CT 06483

P. Geiger

10 Canfield Road

Cedar Grove, NY 07009

G. Grant

General Motors

GM Building 12-167

Detroit, MI

J. Grassi

Fuel Merchants Assn. of New Jersey

66 Morris Avenue

Springfield, NJ 07081

C. L. Green

Ford Products Company

Ford Products Road

Valley Cottage, NY 10989

M. Gunn

U.S. Department of Energy

CE-12

1000 Independence Avenue S.W.

Washington, DC 20585

R. C. Hatter

Danfoss, Inc.

16 Mckee Drive

Mahwah, NJ 07430

A. C. S. Hayden

CDN Combustion Research Lab.

ERL/CANMET

555 Booth Street

Ottawa, Canada K1A OG1

F. Horwath

Suntec Industries, Inc.

2210 Harrison Avenue

Rockford, IL 61125 
No. of

Copies

W. H. Hulick

Monarch Manufacturing Works, Inc.

2501 East Ontario Street

Philadelphia, PA

\section{K. S. Hwang}

Duo-Matic 01sen, Inc. P.0. Box 900

Tilbury, Ontario

Canada

0 . Jeanne

Elf Technologies, Inc.

High Ridge Park, P.0. Box 10037

Stamford, CT 06904-2037

B. R. Kamath

American Burner Corporation

85 Austin Boulevard

Commack, NY 11725

R. A. Kaplan

Wayne Home Equipment

P.0. Box 2257

Fort Wayne, IN 46801

T. Kapus

U.S. Department of Energy

CE 112

1000 Independence Avenue, S.W. Washington, DC 20585

M. D. Kaufman

Circle Combustion Corp.

Southside Avenue

Hast ings-on-Hudson, NY 10706

R. Krajewski

Brookhaven National Laboratory

Building 120

Upton, NY 11973

C. R. Krishna

Brookhaven National Laboratory

Building 120

Upton, NY 11973
No. of

Copies

J. A. Lane

Amtrol, Inc.

1400 Division Road

West Warwick, RI 02893

20 D. Lim

U.S. Department of Energy

CE 112

1000 Independence Avenue, S.W.

Washington, DC 20585

L. Lindtveit

Sid Harvey Industries, Inc.

605 Locust Street

Garden City, NY 11530

5 D. Locklin

Battelle Columbus Laboratories

505 King Avenue

Columbus, $\mathrm{OH} 43201$

10 R. D. Lynch

Executive Vice President

Empire State Petroleum Association, Inc.

8 Westchester Plaza

Executive Park

Elmsford, NY 10523

G. C. Mackenzie

Mobil 0 il Corp.

3225 Gallows Road, Room 3N-314

Fairfax, VA 22037-0001

J. D. Marran

Energy Kinetics

P.0. Box 407

Bernardsville, NJ 07924

V. Marret

Elf Technologies, Inc.

High Ridge Park

P.0. Box 10037

Stamford, CT 06904-2037 
D. Maul

Burnham Corporation

Hydronics Division

2 Main Street

Irvington, NY 10533

50 R. McDonald

Brookhaven National Laboratory

Building 120

Upton, NY 11973

A. Mezzina

Brookhaven National Laboratory

Building 120

Upton, NY 11973

J. Millhone

U.S. Department of Energy

CE 11

1000 Independence Avenue, S.W.

Washington, DC 20585

M. F. Morin

SERVCO OIL, INC.

P.0. Box 686

Wilton, CT 06897

M. J. Myers

Director of Engineering

Peerless Boiler Company

Spring \& Schaeffer Streets

Boyertown, PA 19512

J. Nally

Brookhaven National Laboratory

Building 526

Upton, NY 11973

E. Nordstrom

Amtrol, Inc.

1400 Division Road

West Warwick, RI 02893

H. G. Parry

C. D. Parry Company, Inc.

21 Fort Putnam Street

Highland Falls, NY 10928
L. Post

Alliance to Save Energy

1925 K Street, N.W., Suite 206

Washington, DC 20006

W. M. Ribble

Training Manager

Honeywel1, Inc.

1985 Douglas Drive, N.

Golden Valley, MN 55422-3992

J. Ryan

U.S. Department of Energy

CE 113.2

1000 Independence Avenue, S.W.

Washington, DC 20585

M. T. Scanlon, Jr.

Petroleum Marketing Education

Foundation

101 North Alfred Street

Alexandria, VA 22314

M. Scentesy

Wayne Home Equipment

101 Ridings Way

Lancaster, PA 17601

R. Schildwachter

Schildwachter \& Sons

Bronx, NY

G. Schultz, Editor

Fuel 0il News

P.0. Box 280

Colonia, NJ 07067

T. Seale

Management Analysis Center

11 BD Latour Marbourg

75007 Paris, France

J. R. Shaner

National Petroleum News

P.0. Box 1476

Morristown, NJ 07960 
No. of

Copies

10 B. A. Smith

Vice-President, Operations

New England Fuel Institute

P.0. Box 888

20 Summer Street

Watertown, MA 02172

G. Stamberger

St amberger Associates

308 0sborn Avenue

Pt. Pleasant, NJ 08742

S. Stamberger

Stamberger Associates

919 N. Tioga Street

Ithaca, NY 14850

D. H. Stewart

Griffin-Galbraith Fuel Company

1648 E. "J" Street

Tacoma, WA 98421

G. Stewart

$0 i 1$ Heat Institute of Oregon

P.0. Box 42227

Portland, OR 47242

J. Sweedyk

Sundstrand Heat Transfer

415 Prairie Round

Dowagiac, MI 49047

D. E. Swe igart

Burnham Corporation

1237 Harrisburg Pike

P.0. Box 3079

Lancaster, PA 17604

W. Temple

Wyatt, Inc.

P.0. Box 1805

New Haven, CT 06507

B. Thiel

Fuel Merchants Assn. of New Jersey

66 Morris Avenue

Springfield, NJ 07081
No. of

Copies

D. Tjosvold, President

Yukon Energy Corporation 9890 NE Hwy. 65

Minneapolis, MN 55434

G. Walsh

Meenan 0 i 1 Company, Inc. 3020 Burns Avenue

Wantagh, NY 11793

B. J. Watling

The Carlin Company

601 Marshall Phelps Road

Windsor, CT 06095

J. Wellman

Wayne Home Equipment

Burner Division

$801 \mathrm{Glasgow}$ Avenue

Ft. Wayne, IN 46803

D. P. Werner

Hydrotherm

Rockland Avenue

Northvale, NJ 07647

R. S. Wilkinson

Intelli-Tech Company

P.0. Box 61

Lewis Hill Road

West Newfield, ME 04095

J. I. Woodworth

Hydronics Institute

35 Russo Place, P.0. Box 218

Berkeley Heights, NJ 07922

L. Woodworth

Petroferm

Amelia Island, FL

J. P. Woody

Kinney Oil Company

795 E. Main Street

Bridgewater, NJ 08807 
No. of

Copies

M. Woody

Kinney Oil Company

795 E. Main Street

Bridgewater, NJ 08807

P. J. Zacuto, P.E. Heat Extractor, Inc.

2 Main Street

Melrose, MA 02176

\section{ONSITE}

DOE Richland Operations
No. of

Copies

24 Pacific Northwest Laboratory

R. S. Crowder

R. A. Hutchinson (10)

C. H. Imhoff

B. M. Johnson

D. K. Kreid

R. W. Reilly

T. J. Secrest

P. L. Whiting

Publishing Coordination (2)

Tech. Information (5)

J. J. Sutey 